\title{
Glider monitoring of shelf suspended particle dynamics and transport during storm and flooding conditions
}

\author{
François Bourrin ${ }^{\mathrm{a}, \mathrm{b}, *}$, Gaël Many ${ }^{\mathrm{a}, \mathrm{b}}$, Xavier Durrieu de Madron ${ }^{\mathrm{a}, \mathrm{b}}$, Jacobo Martín ${ }^{\mathrm{c}, \mathrm{d}}$, \\ Pere Puig ${ }^{c}$, Loic Houpert ${ }^{\text {b,e }}$, Pierre Testor $^{f}$, Stéphane Kunesch ${ }^{\text {a,b }}$, Karim Mahiouz ${ }^{\mathrm{g}}$, \\ Laurent Béguery ${ }^{\text {g,h }}$
}

\author{
a Univ. Perpignan Via Domitia, Centre de Recherche et de Formation sur les Environnements Méditerranéens, UMR 5110, 52 avenue Paul Alduy, F-66860 \\ Perpignan, France \\ ${ }^{\mathrm{b}}$ CNRS, Centre de Recherche et de Formation sur les Environnements Méditerranéens, UMR 5110, 52 avenue Paul Alduy, F-66860 Perpignan, France \\ ' ICM-CSIC, Passeig Marítim de la Barceloneta 37-49, 08003 Barcelona, Spain \\ d CADIC-CONICET, Bernardo Houssay 200, 9410 Ushuaia, Argentina \\ e SAMS-SMI, Oban, Argyll PA37 1QA, UK \\ ${ }^{f}$ LOCEAN, UPMC-CNRS-IRD-MNHN, 4 place Jussieu, 75252 Paris Cedex 05, France \\ ${ }^{g}$ CNRS-DT INSU, Zone portuaire de Brégaillon, BP 330, 83507 La Seyne-sur-mer cedex, France

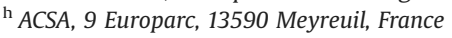

Transfers of particulate matter on continental margins primarily occur during energetic events. As part of the CASCADE (CAscading, Storm, Convection, Advection and Downwelling Events) experiment, a glider equipped with optical sensors was deployed in the coastal area of the Gulf of Lions, NW Mediterranean in March 2011 to assess the spatio-temporal variability of hydrology, suspended particles properties and fluxes during energetic conditions. This deployment complemented a larger observational effort, a part of the MOOSE (Mediterranean Ocean Observing System of the Environment) network, composed of a coastal benthic sta-tion, a surface buoy and moorings on the continental slope. This set of observations permitted to measure the impact of three consecutive storms and a flood event across the entire continental shelf. Glider data showed that the sediment resuspension and transport observed at the coastal station during the largest storm $\left(H_{\mathrm{s}}>4 \mathrm{~m}\right)$ was effective down to a water depth of $80 \mathrm{~m}$. The mid-shelf mud belt, located between 40 and $90 \mathrm{~m}$ depth, appears as the zone where the along-shelf flux of suspended sediment is maximum. Besides, the across-shelf flux of suspended sediment converges towards the outer limit of the mid-shelf mud belt, where deposition of suspended particles probably occurs and contributes to the nourishment of this area. Hydro-logical structures, suspended particles transport and properties changed drastically during stormy periods and the following flood event. Prior to the storms, the shelf waters were weakly stratified due in particular to the presence of cold dense water on the inner- and mid-shelf. The storms rapidly swept away this dense water, as well as the resuspended sediments, along the shelf and towards a downstream submarine canyon. The buoyant river plumes that spread along the shelf after the flooding period provoked a restratification of the water column on the inner- and mid-shelf. The analysis of glider's optical data at different wavelengths suggests that the coastal area and the bottom nepheloid layer during the largest storm are primarily com-posed of coarse particles, probably macroflocs, and that the size of particles decreases further offshore. A similar trend, albeit less contrasted, is observed after the flooding. This work provided a unique synoptic view across the entire shelf of the impact of a typical Mediterranean storm on bottom sediment erosion and particulate fluxes. Repeated glider transects across the southwestern part of the Gulf of Lions shelf per-mitted for the first time to measure continuously the thermo-haline structures, the suspended particles concentrations and size, the current speed, and to estimate the particulate transport before, during and after typical Mediterranean storm events. Glider data complement and compare well with concomitant high frequency time series at fixed stations along the coast and in a downstream submarine canyon.

\footnotetext{
* Corresponding author at: Univ. Perpignan Via Domitia, Centre de Recherche et de Formation sur les Environnements Méditerranéens, UMR 5110, 52 avenue Paul Alduy, F-66860 Perpignan, France.

E-mail address: fbourrin@univ-perp.fr (F. Bourrin).
} 


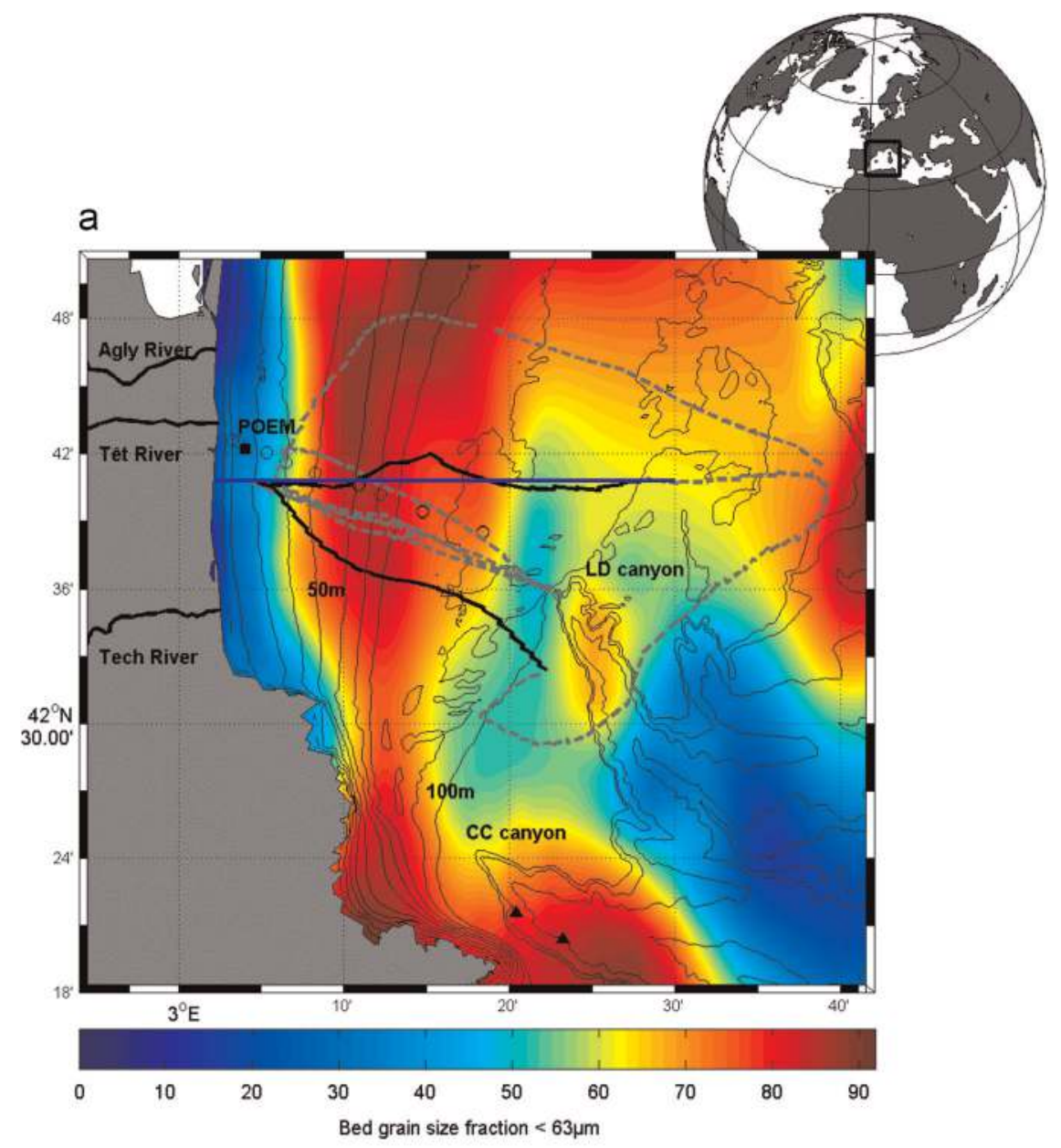

b

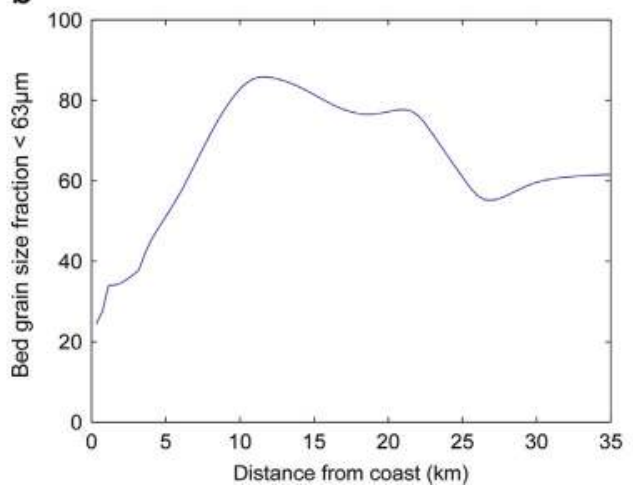

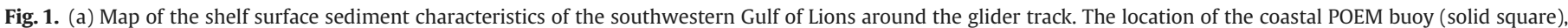

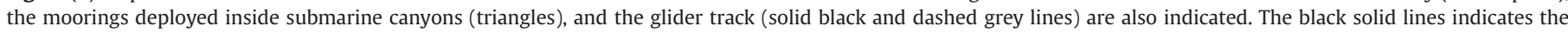

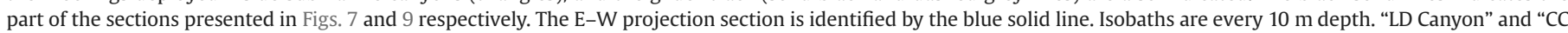

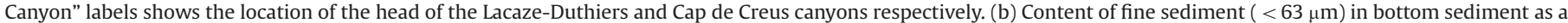

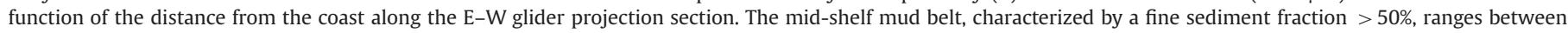

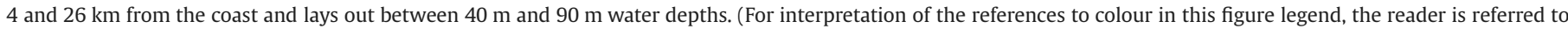
the web version of this article.)

\section{Introduction}

\subsection{Observations of the sediment transport during floods and storms}

Sediment dynamics on continental margins is usually influenced by sediment inputs from rivers. Riverine fine-grained particles commonly accumulate on the mid-shelf and form a mud belt (Hill et al., 2007). Several authors (Cattaneo et al., 2007; Harris and Wiberg, 2002; McCave, 1972) proposed that cross-shelf currents eventually advect fine-grained sediments and that the location and thickness of the fine-grained deposits depends upon the balance between hydrodynamics and sedimentary inputs. In this balance, floods and storms appear as key processes (Moore, 1969; Wright and Coleman, 1974, Harris and Wiberg, 2002, Nittrouer et al., 2007), which are still challenging to witness and to explicitly assess the magnitude on the fine-grained sediment transport (Corbett et al., 2014).

Until recently, most in situ observations of suspended particle 
transport during flood and storm events were gathered at few fixed locations over one or some components of the shelf (inner-, mid-, outer-shelf, and shelf break). Such observations provide precise information on the temporal variability of a narrow water column, but do not enable to describe the spatial gradients across the entire shelf and evaluate the overall suspended particle transport. Remote-sensing observations provide snapshots of the distribution of suspended particles, which are however restricted to the surface layer and to cloud-free days. Likewise, identification of suspended particles properties, especially their concentration, size distribution and composition (mineral or organic), that is central for the understanding of their origin and their fate (Boss et al., 2001b; Curran et al., 2007; Doxaran et al., 2009) suffer from the same gaps in terms of spatial and temporal variability throughout the shelf's water column.

Testor et al. (2010) recapitulated the new sampling capabilities offered by gliders during the last decade in various locations. Glenn et al. (2008) first evaluated the potential of autonomous gliders equipped with physical and optical sensors to study the spatial and temporal variability of sediment resuspension and transport across the Middle Atlantic Bight continental shelf. Lately, Miles et al. (2013) quantified in the same region the spatial variability of sediment resuspension and transport during a large fall storm using gliders as well as fixed platforms (high frequency radars and meteorological buoys). Both studies demonstrated that gliders satisfactorily documented vertical and horizontal gradients of the primary parameters (i.e., temperature, salinity, density, suspended particle concentration, and depth-averaged currents). Moreover, gliders with bio-optical multispectral sensors also efficiently yielded the concentration, size, and composition of suspended particulate matter together with physical properties of the water column (Niewiadomska et al., 2008). Hence, gliders appeared as valuable tools - together with traditional fixed platforms - to improve our understanding of the still poorly known sedimentary responses to stormy events and to provide validation data sets for models.

Here we present a study combining multiple platforms - including mooring, ship, satellite and glider data - to assess the shelf sediment dynamics and transport as well as the main properties of suspended particles during storm and flooding conditions in the Gulf of Lions (GoL) in the north-western Mediterranean.

\subsection{Regional settings}

During the last decades, the Gulf of Lions has been targeted by numerous observational programmes dealing with the presentday particle flux dynamics (Weaver et al., 2006; Durrieu de Madron et al., 2008). Sediment dynamics on this continental shelf is essentially dependant upon sediment inputs from the Rhône River in the northeast and to a lesser extent to several small rivers along the central and western part of the gulf. River inputs, which are essentially active during violent and brief flood events, control the sedimentation rate on the inner-shelf and on prodeltas. These humid events are enhanced by the strong marine winds coming from the East and South-East (E-SE) sectors. Various observational (Bonnin et al., 2008; Bourrin et al., 2008a; Ferré et al., 2005; Guillén et al., 2006; Palanques et al., 2006, 2008; Ogston et al., 2008; Martín et al., 2013) and modelling (Dufois et al., 2008; Ferré et al., 2008; Ulses et al., 2008a) studies emphasized the role of severe E-SE storms on the transport of sediment in suspension and redistribution of the shelf sediments. The E-SE storms have a marked seasonal impact with a maximum occurrence during autumn and winter, and are often concomitant with flooding of the small rivers. The major sedimentary units (sandy inner-shelf interspersed with muddy river prodeltas, mid-shelf mud belt, and silty-sandy outer-shelf; Fig. 1a) reflect the effect of wave and current activity. Observations clearly showed that the sandy innershelf primarily results from the impact of waves. Modelling suggested that the strong cyclonic shelf circulation during E-SE storms favours the south-westward dispersal and accumulation of the fine sediment inputs from rivers on the mid-shelf, while it leads to a significant winnowing of the fine sediment on the outer-shelf. This circulation converges towards the SW end of the gulf that is the main exit from the continental shelf (DeGeest et al., 2008).

Most of the observations obtained until now were collected at few fixed points using benthic tripods or mooring lines on the inner shelf and in canyon heads, while there is a lack of observations and knowledge about the continuity of particle transport and sediment dynamics across the mid and outer-shelf. Moreover, since this transport primarily occurs during storms, there is a specific need to collect data during energetic conditions to better document the variability of suspended particles properties and quantify the water and solid transports across the entire shelf to assess the estimations based on modelling.

\subsection{Presentation of the experiment}

A dedicated study was conducted in the south-western part of the GoL shelf (Fig. 1a), where it narrows and most of the suspended sediment transport converges during E-SE storms and river floods. The study area presents contrasted sedimentological features with: (i) a sandy inner-shelf interspersed with rocky outcrops and muddy prodeltas next to river mouths, (ii) a midshelf mud belt between 40 and $90 \mathrm{~m}$, and (iii) coarser sediment with sandy patches on the outer-shelf between 90 and $200 \mathrm{~m}$ water depth around the Cap de Creus and Lacaze-Duthiers canyon heads. The mid shelf mud belt is characterized by a fine sediment fraction $>50 \%$, ranges between 4 and $26 \mathrm{~km}$ from the coast (Fig. 1b). The overall experiment lasted 2 months, from 25 February 2011 to 28 April 2011, and enabled to monitor the effect of strong E-SE storms that occurred during the first two weeks of March 2011, and the subsequent flooding of the small coastal rivers. While fixed platforms were used both on the inner shelf (buoy and benthic tripod next to the Têt River mouth) and in the southernmost canyon (mooring lines in the Cap de Creus Canyon head, see Fig. 1a), mobile platforms (research vessel, autonomous glider) were also used to sample the entire continental shelf between $15 \mathrm{~m}$ and $200 \mathrm{~m}$ water depth. Satellite images were used to depict when possible the large-scale distribution of suspended particulate matter in the surface layer.

Based on the datasets collected in the Cap de Creus Canyon by moored instruments, hydrographical profiling and vessel-mounted ADCP, Martín et al. (2013) described the sediment transport along the canyon, with a particular focus on the effect of the E-SE storm events. They showed that most of the along-canyon sediment transport took place along the southern canyon flank and during a relatively short episode (13-15 March) of dominant eastern winds comprising two consecutive storms. During this period, a tongue of cold, freshened and turbid water of shelf origin sank into the canyon along its southern flank to depths up to $350 \mathrm{~m}$. The intruding water was less dense than ambient waters, being pushed beyond its equilibrium depth by the storm-induced downwelling. Sediment transport along the canyon flank associated with that water body was well distributed in a range of $200 \mathrm{~m}$ above the bottom. Martín et al. (2013) provided a rough estimation of $1 \times 10^{5} \mathrm{t}$ of suspended sediments being transported into the canyon within the downwelled coastal plume during the 3-day stormy period. Considering that the main contribution of river inputs which flooded during and after the largest storm took place after the major episode of along-canyon sediment transport, they suggested that the erosion of inner shelf sediments by the action of storm waves and currents was likely the primary source 
of sediments feeding the suspended particle pool of the coastal water plume intruding the canyon.

The present work is complementary to the aforementioned paper and describes a comprehensive set of observations collected on the shelf that aims at assessing (i) the variations of the suspended particle concentration, properties, and transport across the entire shelf width before, during and after stormy and flooding events, and (ii) the impact of the mid-shelf mud belt on the suspended sediment supply during the storm.

\section{Materials and methods}

\subsection{Oceanographical observations}

\subsubsection{Coastal buoy data}

Time series of meteorological parameters (air temperature, wind speed and direction), near-surface temperature-salinitydepth (CTD), turbidity and chlorophyll a (Chl-a), current profiles, waves characteristics, and seabed-level were collected at the POEM (Plateforme d'Observation de l'Environnement Méditerranéen) buoy located at $28 \mathrm{~m}$ water depth, $2.5 \mathrm{~km}$ off the Têt River mouth (Fig. 1a). This buoy has a three-point helicoidal anchoring tightly linked to mid-water depth flotation to prevent any sediment resuspension (Bourrin et al., 2008a, b). It sheltered a seabed area allowing the deployment of benthic instruments and protecting them from trawling activities. Hydrological data were collected at $1 \mathrm{~m}$ below the surface using a YSI 6600-EDS CTD probe installed on the buoy. The probe has a CTD sensor and additional optical sensors that measure light backscattering at $880 \mathrm{~nm}$, and fluorescence of Chl-a. Data were recorded every $15 \mathrm{~min}$.

Current and wave data were collected using a $600 \mathrm{kHz}$ Teledyne RDI upward-looking acoustic Doppler current profiler (ADCP) equipped with a wave gauge, deployed on a bottom frame. Highfrequency measurements of near-surface wave orbital velocities, surface track, and pressure were used to compute significant wave height $\left(H_{\mathrm{s}}\right)$, peak period $\left(T_{\mathrm{p}}\right)$ and peak wave direction $\left(D_{\mathrm{p}}\right)$ according to the technical manual of Teledyne RD Instruments (2007). Waves were measured during 20 min bursts every $3 \mathrm{~h}$. Currents were measured at $1 \mathrm{~Hz}$ in $1 \mathrm{~m}$ depth cells from 2 to $27 \mathrm{~m}$ above the bottom (mab), between wave burst measurements and were averaged every $3 \mathrm{~h}$. We used thereafter the following convention for current values: positive northward and negative southward for the along-shelf component, and positive westward and negative eastward for the cross-shelf component. The maximum bottom shear stress $(\tau)$ was calculated using the wavecurrent combination model developed in Madsen and Wood (2002). Inputs for computation are the maximal wave orbital velocity $\left(U_{\mathrm{mw}}\right)$ measured during wave burst from the ADCP, wave period $\left(T_{\mathrm{p}}\right)$, current velocity $\left(u_{\mathrm{z}}\right)$ at $2 \mathrm{~m}$ above the bottom and the wave-current angle $\left(\operatorname{ang}_{\mathrm{wc}}\right)$. The bottom was assumed to be flat and bottom roughness was estimated from mean grain-size at the POEM site.

Acoustic backscattered intensities were measured along the four beams of the ADCP. The acoustic pulse emitted from a single beam of the ADCP has a certain initial intensity, which progressively diminishes as it travels through the water column and is reflected from the suspended particles. Suspended particulate matter (SPM) concentrations were derived from acoustic backscattering signal using Sediview software HR Wallingford (Wallingford, 2003), based on an iterative method to solve a simplified version of the sonar equation (derived from Thorne and Campbell (1992) and Hay (1991)): $\log 10 M_{\mathrm{r}}=\frac{\left\{\mathrm{d} B+2 r\left(\alpha_{\mathrm{w}}+\alpha_{\alpha}\right)-K_{\mathrm{s}}\right\}}{S}$

where $M_{\mathrm{r}}$ is the mass concentration per unit volume of range $r, S$ is the relative backscatter coefficient, $\alpha_{\mathrm{w}}$ is the water attenuation coefficient and $\alpha_{\mathrm{s}}$ is the sediment attenuation coefficient, $K_{\mathrm{s}}$ is the site and instrument constant and $\mathrm{d} B$ is the measured relative backscatter intensity corrected for spherical spreading. The signal measured from the four beams were averaged and forced against in-situ gravimetric SPM concentration measurements. Sediment attenuation was estimated using relative effective particle size of $25 \mu \mathrm{m}$ measured prior to the experiment with an in-situ Sequoia LISST-100 type B (data not shown). Calibration constant $K_{\mathrm{s}}$ and backscatter coefficient $S$ used for the calibration were 35 and 20 respectively.

Seabed elevation data were collected using two NKE Altus $2 \mathrm{MHz}$ sonic altimeters deployed on both sides of the buoy's sheltered area. These instruments positioned at $\sim 40 \mathrm{~cm}$ above the bed, were mounted on light tripod frames, whose legs were tightly screwed into the sediment, hence preventing any sediment scouring under the transducer. They enabled to measure seabed level variation with a $0.6 \mathrm{~mm}$ resolution and maximum echoamplitude intensities related to the quantity of suspended sediments.

\subsubsection{Glider dato}

The glider-based time series consisted of lines of 25 to $50 \mathrm{~km}$ long (Fig. 1a) that run across the shelf from the POEM Buoy $(28 \mathrm{~m}$ water depth) to the shelf edge (100 m water depth) in the vicinity of the Lacaze-Duthiers canyon head (Fig. 1a). The autonomous glider was a coastal (30-200 m) Teledyne Webb Research Slocum (Davis et al., 2002) that moved at an average speed of $20-30 \mathrm{~cm} \mathrm{~s}^{-1}$ in a sawtooth-shaped trajectory between $1 \mathrm{~m}$ below the surface and 1-2 $\mathrm{m}$ above the seabed. Glider diving parameters were adjusted during the mission to drive the glider as near as possible to the bottom without touching the seabed. Near surface (0-1 m) data were solely collected when the glider surfaced, once every 6 dives, for getting new position fix and data transmission. The glider compass measurements were provided by an on-board precision navigation TCM3 (PNI). The calibration of the compass was carried out before and after the deployment and the accuracy of the current estimates is the order of $1 \mathrm{~cm} / \mathrm{s}$. By dead reckoning using the glider compass bearing during the dive, estimates of depth-averaged current were calculated based on the difference between the glider's expected surfacing location and the actual new GPS position (Webb Research Slocum manual, 2005). Given the average horizontal speed, it usually took about 1.5 day to cross the shelf. The glider was equipped with an unpumped Seabird SBE-41CP CTD sensor, 1 WetLabs ECO-BB2FLS bio-optical sensor puck and 1 WetLabs ECO-FLNTU. Temperature and conductivity measurements were corrected for thermal lag effect to avoid salinity bias following the work of Morison et al. (1994) extended by Garau et al. (2011). The ECO-BB2FLS provided light backscattering measured at 2 different wavelengths (532 and $880 \mathrm{~nm}$ ) and fluorescence of the CDOM (Coloured Dissolved Organic Matter). The ECO-FLNTU provided light scattering at $700 \mathrm{~nm}$ calibrated in NTU (Normalized Turbidity Units) and the fluorescence of Chl-a.

The strong southward currents during the storms forced to adjust the trajectory by moving away from the initial straight route to cancel out the drift, thus yielding to curved paths (Fig. 1a). The cross-shelf section achieved after the flood period, following the stormy period, was oriented westward because the starting point was located NE of the head of the canyon in an area where lower currents allowed to better control the navigation of the glider. For the sake of consistency and clarity, CTD and optical data along the different glider paths were projected along a W-E section running 
across the shelf from the coastline, south of the Têt River mouth, to the $100 \mathrm{~m}$ isobaths on the outer-shelf (see blue line on Fig. 1a). The projection of the observations was carried out according to depth. The projected data were then linearly interpolated to obtain fields with a $1 \mathrm{~m}$ vertical resolution and $100 \mathrm{~m}$ horizontal resolution.

The glider provided an estimate of the surface to bottom vertically and horizontally averaged velocity (drift) between two surfacings, where its position was precisely determined by GPS. To further characterize the along-shelf current structure along this section, geostrophic velocities were estimated to determine how much the along-shelf flow was affected by the cross-shelf density field and describe the vertical shear in the water column (Pond and Pickard, 1983). The baroclinic component of the geostrophic velocities was first derived using the glider's interpolated density field, and using a zero bottom reference level. The absolute velocity field was subsequently derived by adjusting the depth-averaged geostrophic velocities to the corresponding glider's drift normal to the section interpolated on the same interval as for the geostrophic velocity profiles. The correction from the glider's drift includes the barotropic geostrophic component as well as ageostrophic terms, such as currents induced by surface wind stress and bottom friction.

\subsubsection{Ship data}

Vertical profiling of water column properties was conducted during the CASCADE (CAscading, Storm, Convection, Advection and Downwelling Events) cruise (1-23 March 2011), covering a wide set of coastal, shelf, slope, and basin stations. The casts used in this work are restricted to a section of 9 stations performed along the glider section between 10 and $90 \mathrm{~m}$ water depth on 17 March 2011 (see Fig. 1a for station locations). Casts were carried out using a Seabird 911Plus CTD probe equipped with a SBE 32 Carousel water sampler. The data included CTD, dissolved oxygen concentration, light attenuation at $660 \mathrm{~nm}$ (C-Star sensor), light backscattering at $880 \mathrm{~nm}$ (Seapoint sensor), Chl-a fluorescence. The casts were conducted from the surface to less than $1 \mathrm{~m}$ above the seafloor. Water samples were collected and filtered on board on $0.45 \mu \mathrm{m}$ nuclepore filters. Dry weights were used to convert the turbidity signals (expressed in NTU) from POEM subsurface CTD backscattering sensor (Bb, $880 \mathrm{~nm}$ ), shipboard CTD backscattering sensor $(\mathrm{Bb}, 880 \mathrm{~nm})$ and glider ECO-FLNTU $(\mathrm{Bb}, 700 \mathrm{~nm})$ sensor into SPM concentrations (Fig. 2). The glider FLNTU sensor directly gives turbidity output in NTU. We used a spatial objective analysis to match turbidity measurements from the glider with calibrated NTU signal from the subsurface CTD backscattering sensor calibrated versus gravimetric measurements each time the glider crossed nearby the buoy. We used a type-II linear regression analysis between SPM and turbidity units to derive a model to predict SPM concentrations from FLNTU glider sensor. This analysis is implemented in the MATLAB programme lscubic.m by E.T. Peltzer (for details, see http://www.mbari.org/staff/etp3/regress. htm). This model reduces the uncertainty for estimations of low turbidity values.

\subsubsection{Canyon mooring data}

Two instrumented mooring lines were deployed during the CASCADE cruise (3-21 March 2011) along the western flank of the Cap de Creus Canyon at depths of $290 \mathrm{~m}$ and $365 \mathrm{~m}$ respectively (Fig. 1a). Both lines were equipped with a downward-looking $300 \mathrm{kHz}$ RDI ADCP at $160 \mathrm{mab}$, three Seapoint backscattering sensors (OBS at $880 \mathrm{~nm}$ ) at 10, 75 and 115 mab respectively, and a Seabird SBE 37-SMP CTD probe at 8 mab. Results from these moorings are described in detail in Martin et al. (2013). The OBS sensor at 10 mab was calibrated using the generic equation from Guillén et al. (2000), which is based on statistical analysis of different sets of turbidity data from the same region.

\subsection{Ancillary data}

\subsubsection{River data}

Hourly water discharges of rivers opening to the Gulf of Lions (Rhône, Hérault, Orb, Aude, Agly, Têt, Tech, and Fig. 3b) were measured by gauging stations located near river mouths and provided by the Compagnie Nationale du Rhône and the French

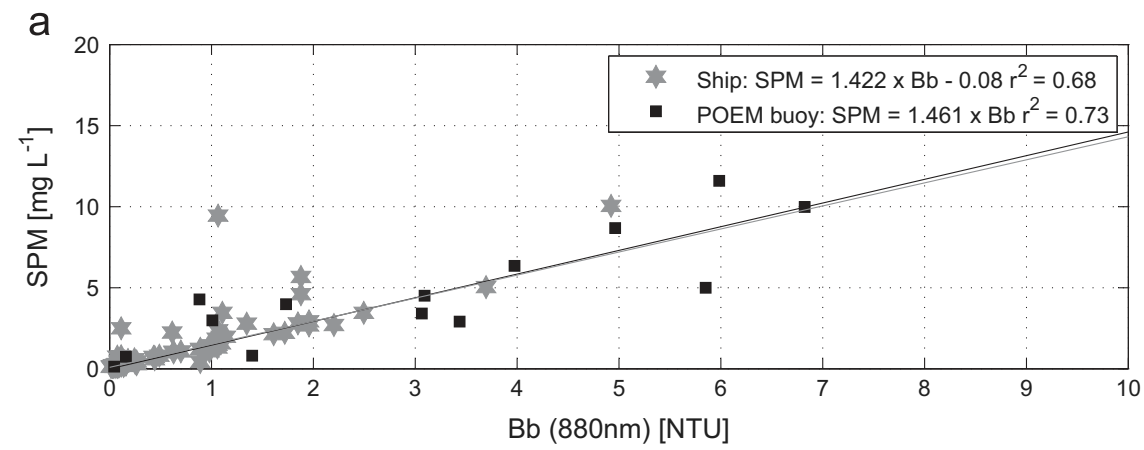

b

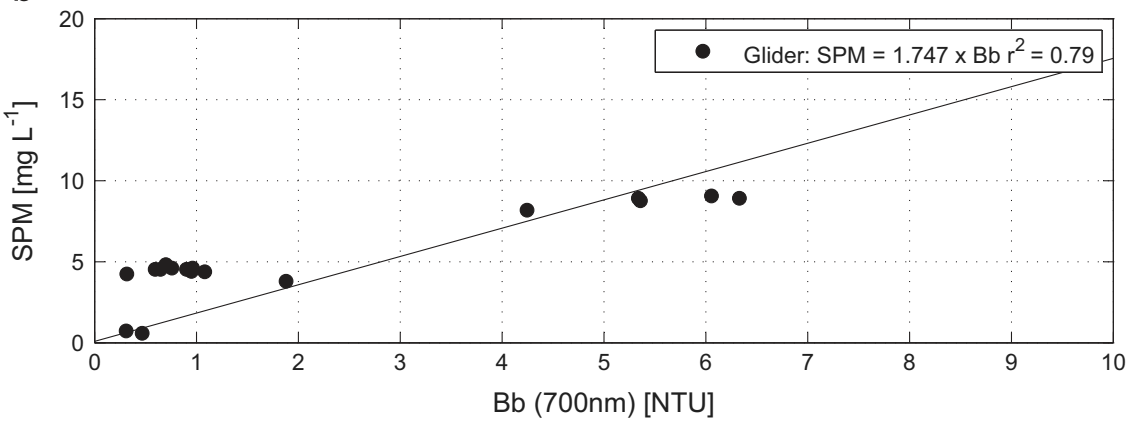

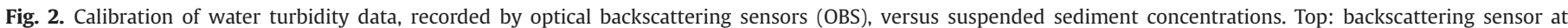
$880 \mathrm{~nm}$ from subsurface POEM buoy (YSI OBS) and ship-board CTD (Seapoint OBS). Bottom: backscattering sensor at $700 \mathrm{~nm}$ from glider (Wet-Labs FLNTU). 

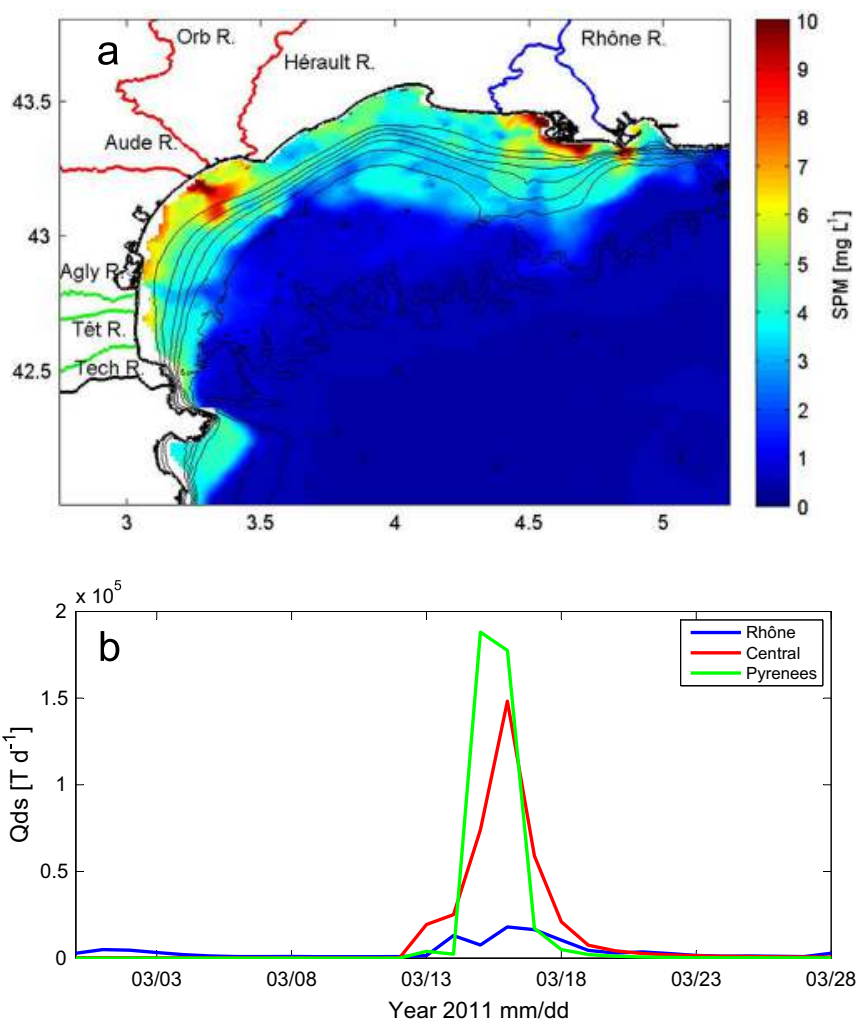

Fig. 3. Top: Satellite picture of suspended particulate matter in the Gulf of Lions during 19 March 2011 showing the river turbid plumes along the Gulf of Lions coast. The picture is a merge product from MODIS and MERIS provided by IFREMER Nausicaa. Bottom: Daily solid discharges from rivers. The central cluster combines the Hérault, Orb and Aude rivers, and the Pyrenean cluster combines Agly, Têt and Tech rivers.

national data bank "HYDRO" (http://www.hydro.eaufrance.fr/ac cueil.html). Solid discharges were estimated using updated calibrations for each river based on the work of Bourrin et al. (2006) (Sadaoui M., personal communication). Sources of Hérault, Orb and Aude rivers are located in the Massif Central and sources of Agly, Têt and Tech in the Pyrenees. When pooled, they are thereafter referred in the text as "Central", "Pyrenean" and Rhône rivers (Fig. 3b).

\subsubsection{Satellite data}

Spatial maps of daily SPM concentrations (Fig. 3a), with a $1 \mathrm{~km}$ resolution, were obtained by merging products from Moderate Resolution Imaging Spectroradiometer (MODIS) on Aqua satellite and Medium-spectral resolution, imaging spectrometer (MERIS) on Envisat satellite. Products, analysis and calibrations used were provided by IFREMER Nausicaa services and OC5 IFREMER algorithms for SPM and Chl-a concentrations estimations from Gohin and Stanev (2011).

\subsection{Derivation of particle properties}

Glider based WET-Labs ECO sensors FLNTU $(\lambda=700 \mathrm{~nm})$ and $\operatorname{BB} 2 \mathrm{FLS}(\lambda=532$ and $880 \mathrm{~nm})$ where used to derive the particulate backscattering coefficients $\left(b_{\mathrm{bp}}\right)$, and to approximate the mean particle size. WET-Labs ECO sensors gave the scattering $[\beta(\theta)]$ at one angle (117 and 140 deg for BB2FLS and FLNTU sensors respectively from Sullivan et al. (2010)) in the backward direction. While the BB2FLS sensor directly gave the total scattering $\left[b_{\mathrm{b}}(\lambda)\right]$ for each wavelength, the FLNTU sensor was factory calibrated in NTU output. The total scattering was then extracted from the raw
NTU signal by multiplying by the Beta Scale Factor. This factor was obtained by multiplying the NTU Scale Factor by a coefficient ( 0.0025 for this FLNTU unit). The particulate backscattering coefficients at each wavelength $\left[b_{\mathrm{bp}}(\lambda)\right]$ was then calculated from the particulate scattering $\left[b_{\mathrm{p}}(\lambda)\right]$ by subtracting the scattering due to pure water from the relation described in Morel (1974).

In marine waters, the spectral slope of the particulate scattering in visible and near infra-red decreases monotonically with increasing wavelength and is approximated by a hyperbolic model: $b_{\mathrm{bp}}(\lambda) \sim A_{\mathrm{c}} \times \lambda^{-\gamma}$, where $\gamma$ is the spectral slope and $A_{\mathrm{c}}$ is the corresponding amplitude (Boss et al., 2001a, 2001b). The size dependence of the number of particles, $N(\mathrm{D})$, can be described by a the power-law function $N(D)=N_{0}\left(D / D_{0}\right)^{-\xi}$, and has a mean particle size $\approx D_{\min } \times(1-\xi) /(2-\xi)$ with $D_{\text {min }}$ being the minimum observable particle size. Boss et al. (2001a) reported a relationship between the exponent $\xi$ and the spectral slope $\gamma$, namely $\xi=\gamma+3-0.5 \exp (-6 \gamma)$. The mean particle size thus increases with decreasing $\xi$, and hence the spectral slope $\gamma$ (the lower the $\gamma$, the higher the contribution of large particles to the total number of particles, and reciprocally). Loisel et al. (2006) exemplified the use of $\gamma$ from satellite remote sensing of the global ocean as an index characterizing the contribution of small versus large particles size to the total particulate assemblage. In the present study, we applied this method to derive an index of the overall particle size repartition in the coastal area from glider-based measurements. The spectral slope, $\gamma$ is calculated as the slope of the linear regression between $\log _{\mathrm{e}}\left(b_{\mathrm{bp}}(\lambda)\right)$ and $\log _{\mathrm{e}}(\lambda)$ [i.e., $\left.\log _{\mathrm{e}}\left(b_{\mathrm{bp}}(\lambda)\right)=\log _{\mathrm{e}}\left(A_{\mathrm{c}}\right)-\gamma \times \log _{\mathrm{e}}(\lambda)\right]$ and using $\lambda=532,700$ and $880 \mathrm{~nm}$ (Fig. 4)

\section{Results}

\subsection{Meteorological and hydrodynamical conditions}

\subsubsection{Wind, waves, and currents}

Time series of meteorological and wave data recorded by the POEM coastal buoy during winter 2010-2011 are shown in Fig. 5. A period of sustained NW winds (Tramontane) with speeds up to $15 \mathrm{~m} \mathrm{~s}^{-1}$ occurred in late February 2011 prior to the start of the experiment (Fig. 5a). During the first 2 weeks of March, winds veered from the northwest to the southeast (marine winds). Three successive south-eastern storms occurred during March, peaking on 8, 13 and 15 March 2011 with maximum significant wave heights $\left(H_{\mathrm{s}}\right)$ of $3.2,4.6$ and $3.7 \mathrm{~m}$ (Fig. 5b) and maximum wave

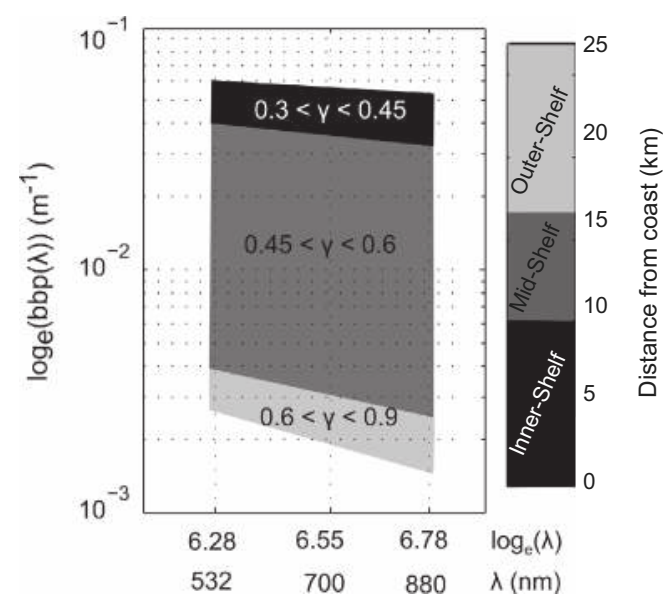

Fig. 4. Example of spectral slopes of backscattering coefficient $(\gamma)$ for the inner, mid and outer-shelf. This coefficient is calculated as the slope of the linear relationship between $\log _{\mathrm{e}}\left(b_{\mathrm{bp}}(\lambda)\right)$ and $\log _{\mathrm{e}}(\lambda)\left[\log _{\mathrm{e}}\left(b_{\mathrm{bp}}(\lambda)\right)=\log _{\mathrm{e}}\left(A_{\mathrm{c}}\right)-\gamma \times \log _{\mathrm{e}}(\lambda)\right]$ estimated for $\lambda=550,700$ and $880 \mathrm{~nm}$. 
a

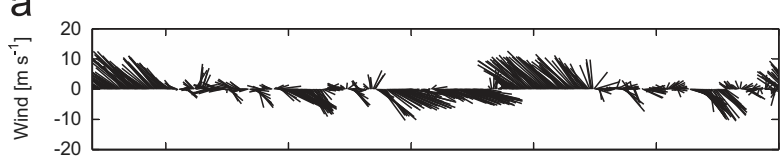

b
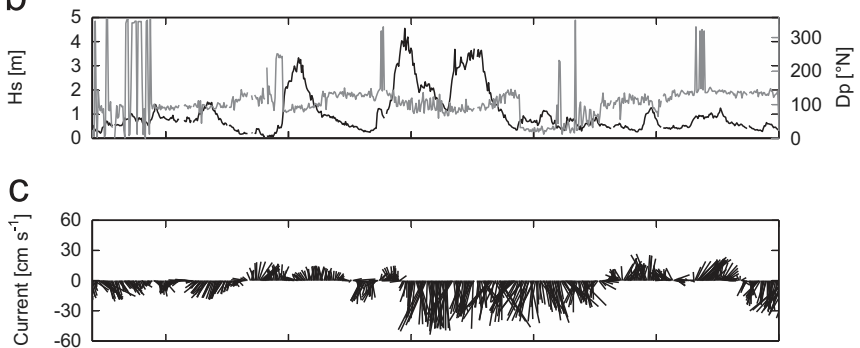

d
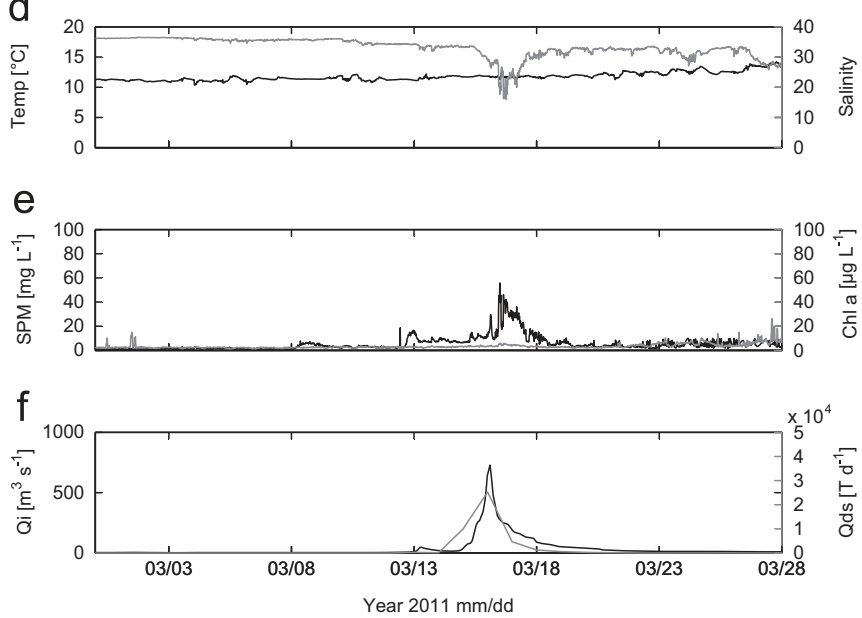

Fig. 5. Time-series of atmospheric and oceanographic conditions at the POEM station and discharges from the Têt River between late February and late March 2011. (a) wind, (b) significant wave height $\left(H_{\mathrm{s}}\right)$ and peak wave direction $\left(D_{\mathrm{p}}\right)$, (c) depth-averaged current, (d) subsurface temperature and salinity, (e) subsurface SPM and Chlorophyll-a concentration, (f) daily Têt river liquid $\left(Q_{i}\right)$ and solid $\left(Q_{d s}\right)$ discharges. By convention wind direction indicates its origin, while current direction points at its destination.

peak periods $\left(T_{\mathrm{p}}\right)$ of 9.4, 9.7 and $10.1 \mathrm{~s}$ respectively (Martín et al., 2013). These wave conditions correspond to typical winter storms in the region (Guizien, 2009). The 13 March storm was the most remarkable of the three in terms of wave energy, particularly in the central part of the GoL, its effects being comparatively milder in its south-western sector (DREAL, 2011). On the inner-shelf, strong southward along-shore currents with maximum speed of $55 \mathrm{~cm} \mathrm{~s}^{-1}$ prevailed during the stormy period (Fig. 5c).

\subsubsection{Rivers discharges and plumes}

River solid discharge for the different rivers of the Gulf of Lions during winter 2010-2011 are shown in Fig. 3b. The sustained SE winds from 12 to 16 March pulled a Mediterranean humid air mass towards southern France, forcing precipitation by orographic control on the Massif Central and above all on the Pyrenees. In contrast, precipitations were abnormally weak on the Rhône watershed (Eau France, 2011). As a consequence, the contribution of western rivers to the total solid discharge in the GoL was unusually high, accounting for up to $85 \%$ during this event, contrasting with a usual annual contribution of only $10 \%$ (the rest corresponding to the Rhône River alone). The highest solid discharges of coastal rivers were measured on 16 March with a maximum of 1.9 and $1.5 \times 10^{5} \mathrm{t} \mathrm{d}^{-1}$ respectively for Pyrenean and Central rivers compared to a maximum of $0.2 \times 10^{5} \mathrm{t} \mathrm{d}^{-1}$ for the Rhône River (Fig. 3b).
The river plumes were clearly seen on satellite picture (Fig. 3a), and their coalescence due to the apparent cyclonic along-shore flow formed a large turbid ribbon covering the inner and middle shelf.

In the study area, the Têt River water and solid discharges peaked at $728 \mathrm{~m}^{3} \mathrm{~s}^{-1}$ and $4 \mathrm{td}^{-1}$, respectively (Fig. 5f). While subsurface temperature did not show any significant change (Fig. 5d), the arrival of fresh and turbid water shortly after the peak of the flood was measured at the POEM buoy with subsurface salinity down to 20 (Fig. 5e). A first significant peak of SPM concentration (up to $15 \mathrm{mg} \mathrm{L}^{-1}$ ) was observed the 13 March associated to a small increase of the river discharge but the maximum of SPM concentration was observed immediately after the flood peak with values up to $50 \mathrm{mg} \mathrm{L}^{-1}$. No significant change in the subsurface Chl-a content was observed during and after the flood except the 28 March probably due to biofouling effect on the probe.

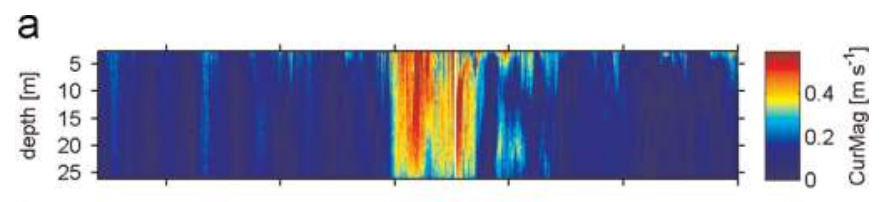

b

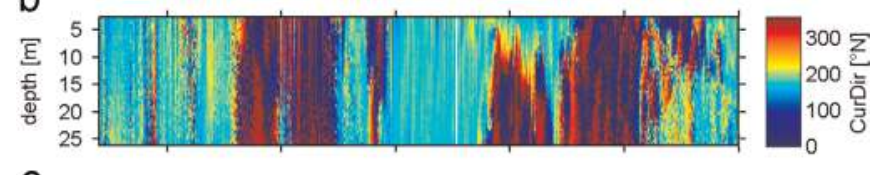

C

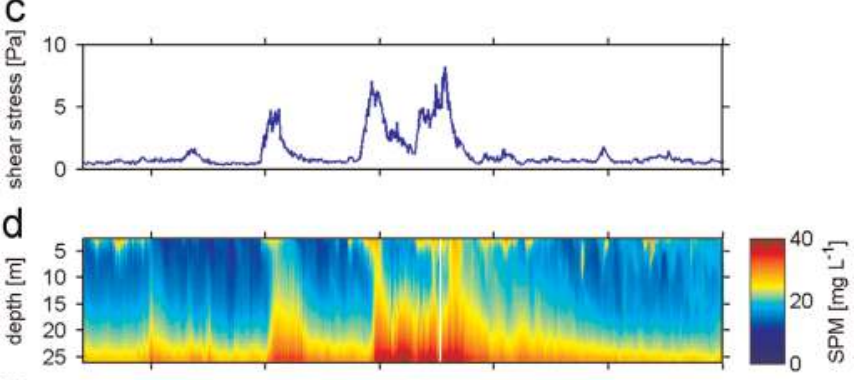

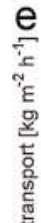

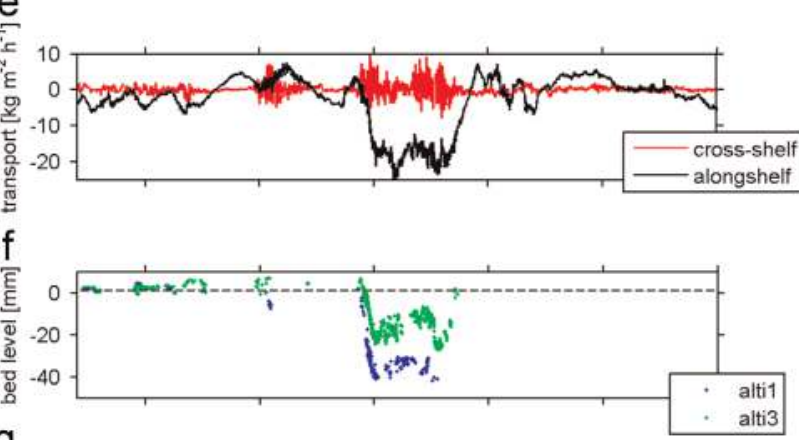

g

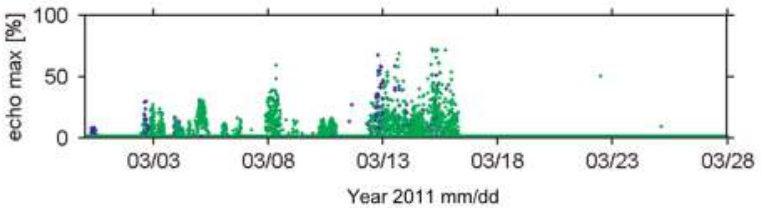

Fig. 6. Bottom-mounted ADCP and altimeters measurements at the POEM station between late February and late March 2011. (a) Current magnitude, (b) current direction, (c) bottom shear stress, (d) suspended sediment concentration derived from ADCP backscattered intensity (e) particulate transport in the cross-shelf (red, + eastward and - westward) and along-shelf (blue, + northward and - southward) directions, (f) seabed elevation, and (g) altimeter backscattered intensity (maximum echo amplitude). (For interpretation of the references to colour in this figure legend, the reader is referred to the web version of this article.) 
3.2. Shelf hydrodynamics and suspended particulate matter transport during the storm and the subsequent flood

\subsubsection{Fixed observations at the coastal station}

ADCP-derived profiles of current and SPM concentrations at the POEM buoy are presented in Fig. 6. Current speed is generally relatively homogenous all over the water column with average speed of about $10-20 \mathrm{~cm} \mathrm{~s}^{-1}$ (Fig. 6a, b), except during the E-SE storm period where current peaked at $55 \mathrm{~cm} \mathrm{~s}^{-1}$ (Fig. 6a, b). Current direction alternately veered from northward to southward during the measurement period and was straight southward during the stormy period (12-16 March). Total (combined wave and current-induced) bottom shear stress showed the occurrence of three stormy events with strong stress values. The last two storms on the 12-13 March and 14-15 March peak at 6.8 and 7.9 Pa respectively (Fig. 6c).

Prior to the storms, SPM concentration profiles showed a bottom turbid layer of about $10 \mathrm{~m}$ thick with concentration varying from $5 \mathrm{mg} \mathrm{L}^{-1}$ at the upper limit of the turbid layer to $13 \mathrm{mg} \mathrm{L}^{-1}$
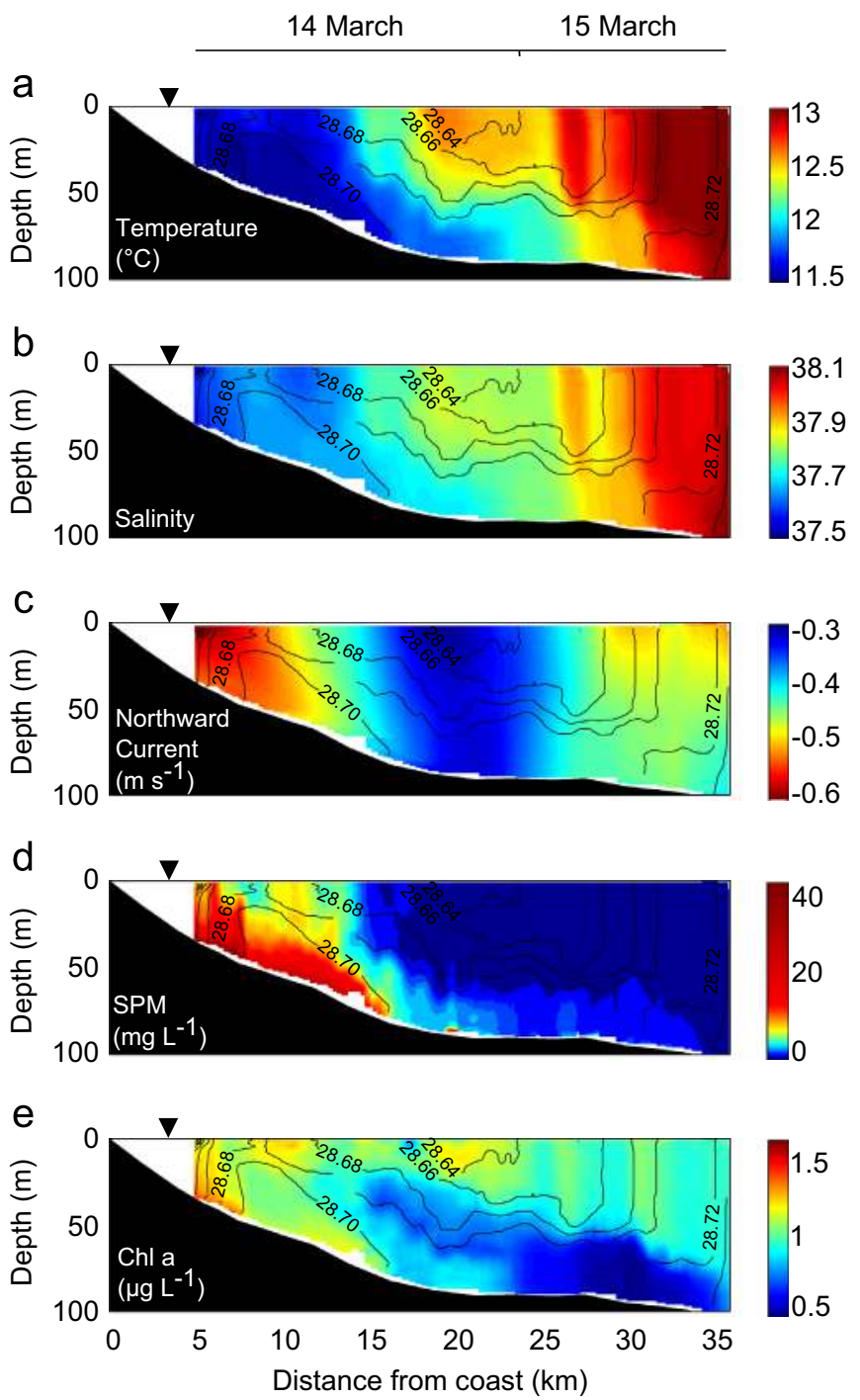

Fig. 7. Cross-shelf hydrography between the POEM coastal buoy (triangle on top of each panel) and offshore along the projected transect (blue line in Fig. 1) based on glider measurements during a E-SE storm (14-15 March 2011). (a) temperature, (b) salinity, (c) along-shelf current velocity (+ northward, - southward), (d) suspended particulate matter concentration, and (e) Chlorophyll-a concentration. The contour-lines on each figure represent iso-values of the density anomaly sigma-theta. (For interpretation of the references to colour in this figure legend, the reader is referred to the web version of this article.) at 2 mab. During the storms, SPM concentrations increased up to $40 \mathrm{mg} \mathrm{L}^{-1}$ close to the seabed, and the bottom turbid layer sometimes extend up to $20 \mathrm{mab}$ (Fig. 6d). The along- and crossshore particle transport remained low during the first storm on the 8-9 March, due to moderate stress associated to this event, but strongly increased up to $-20 \mathrm{~kg} \mathrm{~m}^{-2} \mathrm{~h}^{-1}$ in the along-shore direction (toward the south) for the following storms (Fig. 6e). Seabed elevation measurements and near-bottom echo amplitude from the ALTUS altimeters indicated a significant erosion of the seabed between 25 and $40 \mathrm{~mm}$ (Fig. 6f), and a significant increase of the backscattering intensity (Fig. $6 \mathrm{~g}$ ) during the E-SE stormy period (12-16 March). It seems that the seabed level rose back to its original level immediately after the storm.

\subsubsection{Cross-shelf observations}

The glider permitted to characterize the hydrological and hydrodynamical conditions across the shelf during the two strongest storms (12-13 March and 14-15 March). These two sections showed comparable structures, and the results from the latter section are presented in Fig. 7. The inner and mid-shelf were occupied by a core of colder, fresher but slightly denser water, forming in its distal part a thick bottom wedge reaching depth up to $90 \mathrm{~m}$, underneath a lens of lighter water spanning over the outer-shelf. A density front thus separated the denser water on the inner and mid-shelf from the warmer, saltier, and lighter water on the outer-shelf. Further off-shore appeared typical warmer, saltier slope water getting onto the shelf. A bottom nepheloid layer 20$30 \mathrm{~m}$ thick with particulate concentrations up to $40 \mathrm{mg} \mathrm{L}^{-1}$ near the coast, and $<5 \mathrm{mg} \mathrm{L}^{-1}$ on the outer-shelf was associated to the coastal plume of denser water. Moderate Chl-a concentrations (up
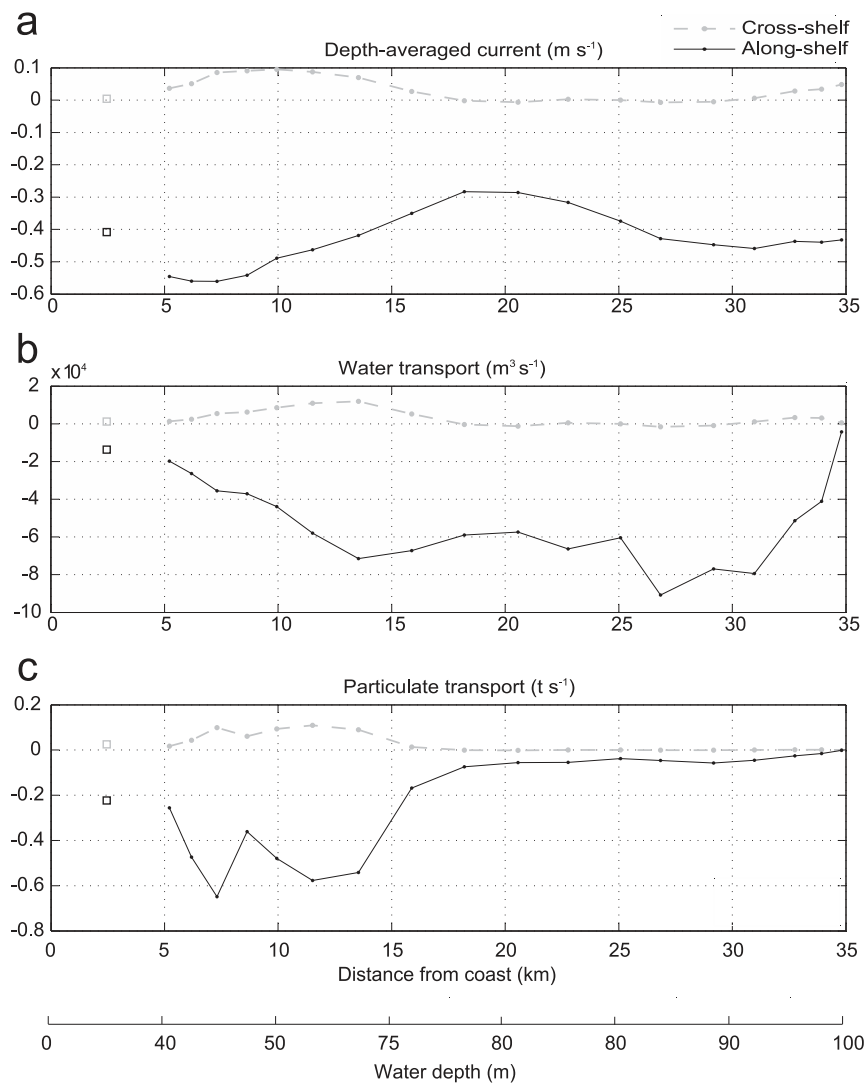

Fig. 8. Cross-shelf and along-shelf components of (a) depth-averaged current (b) water transport, (c) suspended particles transport derived from glider measurements during the storm (14-15 March 2011). The values at a distance of $2.5 \mathrm{~km}$ off the coast are derived from the bottom-mounted ADCP measurement at the POEM station (squares). 
to $2 \mu \mathrm{g} \mathrm{L}^{-1}$ ) appeared in both the surface layer and the bottom layer close to the inner shelf (up to $50 \mathrm{~m}$ deep). The current profiles at the POEM buoy (Fig. 6a, b) and along the cross-shelf section (Fig. 7c) indicated a relative vertical homogeneity of the velocity of currents during the storm.

Based solely on the depth-averaged currents estimated from the glider drifts, the cross-shelf and along-shelf vertically averaged components of the currents, water and particle transports across the shelf during the storm are presented in Fig. 8. The cross-shelf current and transport components, which were low at the POEM buoy at a water depth of $28 \mathrm{~m}$ (Fig. 6e), were oriented off-shore with a maximum on the mid-shelf (water depths between $30 \mathrm{~m}$ and $80 \mathrm{~m}$ ), and vanished again on the outer-shelf. The instantaneous cumulated northward cross-shelf transport of water and particles on the inner and mid-shelf during the storm amounted to $6 \times 10^{5} \mathrm{~m}^{3} \mathrm{~s}^{-1}$ and $0.5 \mathrm{t} \mathrm{s}^{-1}$ respectively (Fig. $8 \mathrm{~b}$ and c). The along-shelf current component was always southward with maximum speeds near the coast, and minimum speeds for water depths between 70 and $80 \mathrm{~m}$ depth at the level of the core of lighter water (Fig. 7c). The alongshelf transport of water increased with the water depth and was

\section{March}

19 March
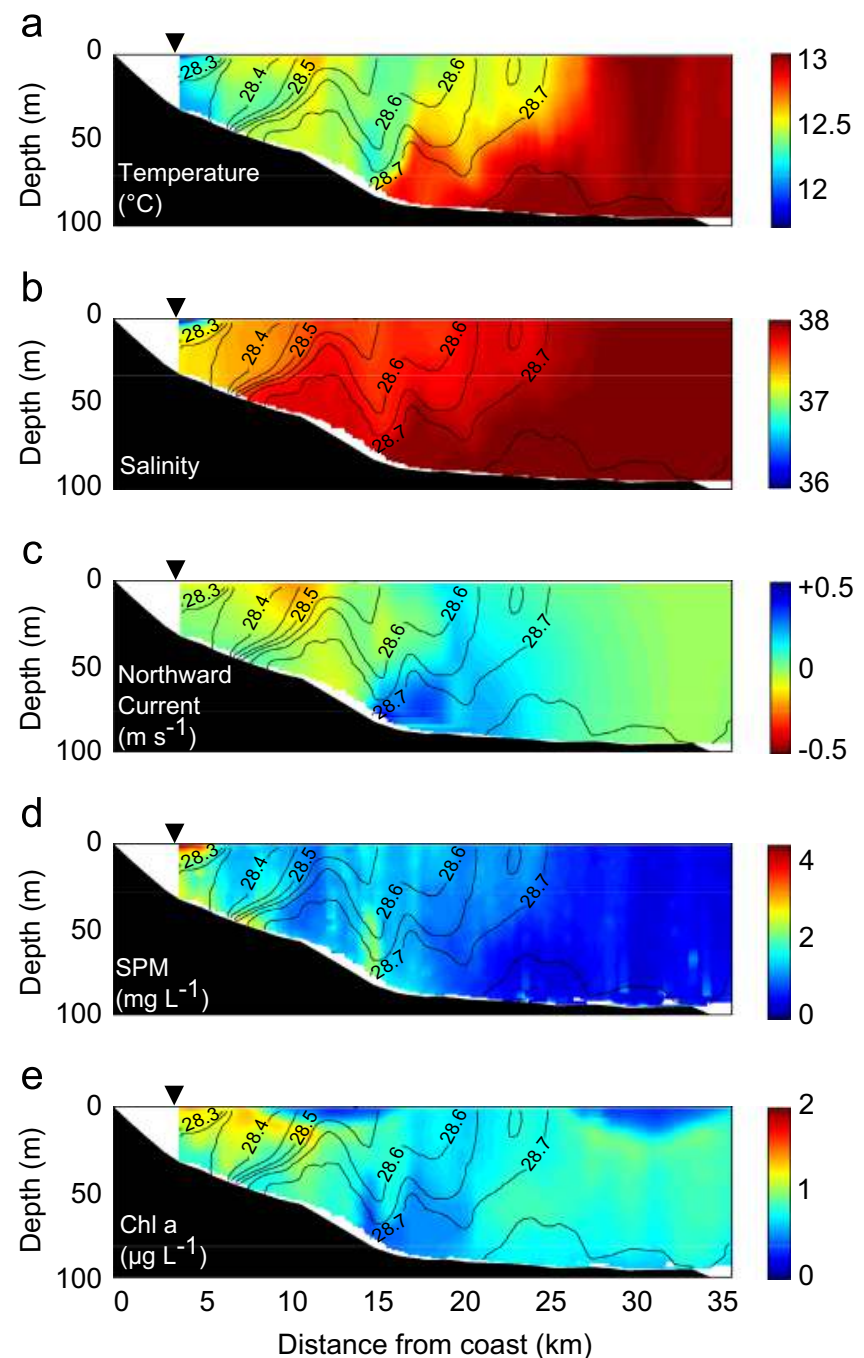

Fig. 9. Cross-shelf hydrography between the POEM coastal buoy and offshore along the projected transect (blue line in Fig. 1) based on glider measurements during and after the flood (19-20 March 2011). (a) temperature, (b) salinity, (c) along-shelf current velocity, (d) suspended particulate matter concentration, and (e) Chlorophyll-a concentration. (For interpretation of the references to colour in this figure legend, the reader is referred to the web version of this article.) maximum on the outer-shelf. However, the along-shelf transport of particle was maximum on the inner and mid-shelf, and the instantaneous cumulated along-shelf transport of water and particle throughout the section amounted to $-95 \times 10^{5} \mathrm{~m}^{3} \mathrm{~s}^{-1}$ and $3.9 \mathrm{t} \mathrm{s}^{-1}$ respectively. Values of depth-averaged current, water transport and particle transport at the POEM site based on ADCP measurements at $28 \mathrm{~m}$ depth are reported on Fig. 8 and are of the same order than glider estimated values at the coast. Considering an area of about $3.75 \times 10^{4} \mathrm{~m}^{2}$ between the coast and the glider covered area, southward depth-averaged current, water and particulate transport are estimated to $-0.41 \mathrm{~m} \mathrm{~s}^{-1},-1.5 \times 10^{4} \mathrm{~m}^{3} \mathrm{~s}^{-1}$, and $0.21 \mathrm{t} \mathrm{s}^{-1}$ respectively.

A four-day flood (15-18 March) followed the stormy period (Fig. 5f). A glider section was performed at the end of the flooding period (19-20 March), and the observed hydrographical conditions are presented in Fig. 9. Significant changes were observed with respect to the stormy conditions. The offshore end of the Têt River freshwater surface plume was clearly visible 4 to $7 \mathrm{~km}$ off the coast, and corroborated the observations at the POEM buoy (Fig. $5 \mathrm{~d}$, e and f). The influence of freshwater inputs from river upstream of the study area was detected at the surface as far as $20 \mathrm{~km}$ off the coast (taking the isohaline 37.5 or isopycnal $28.6 \mathrm{~kg} \mathrm{~m}^{-3}$ as upper limits). A sharp density front separating the main region of freshwater influence and offshore water appeared around $10 \mathrm{~km}$ off the coast. Suspended particle concentrations were drastically lower than during the stormy period, and the highest concentrations (up to $5 \mathrm{mg} \mathrm{L}^{-1}$ ) were confined to the Têt River plume. A diffuse bottom nepheloid layer about $10 \mathrm{~m}$ thick extended over the inner and midshelf. Chl-a concentrations showed highest values (up to $2 \mu \mathrm{g} \mathrm{L}^{-1}$ ) close to the coast in a subsurface layer extending across the region of freshwater influence.

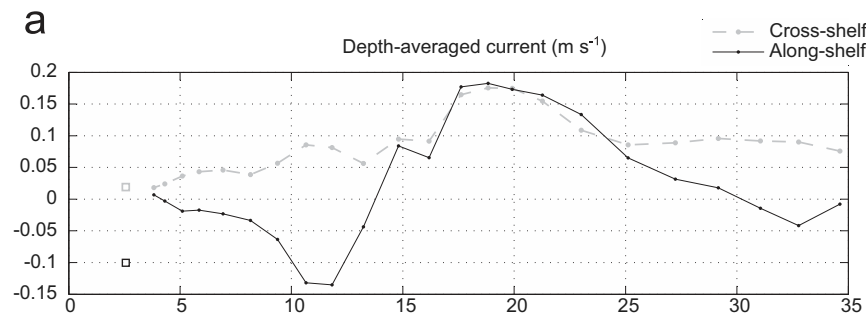

b

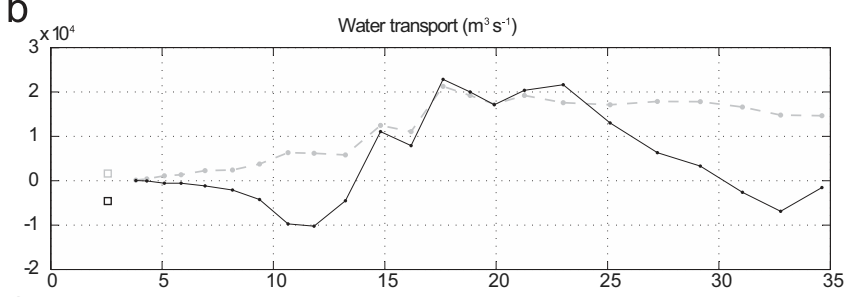

C

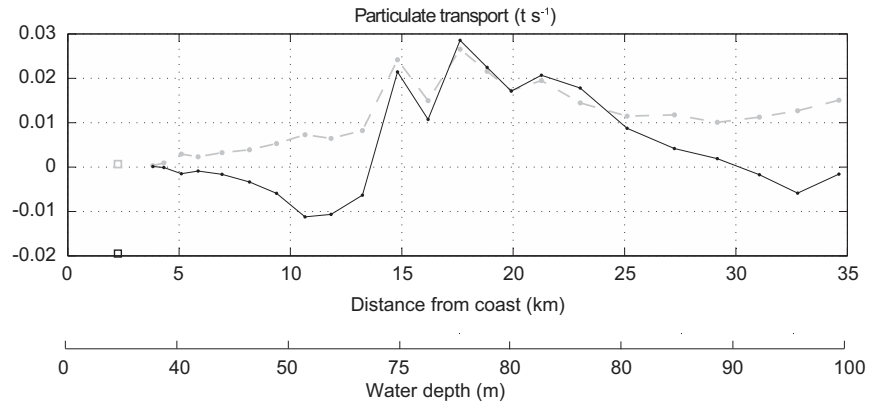

Fig. 10. Cross-shelf and along-shelf components of (a) depth-averaged current, (b) water transport, (c) suspended particle transport derived from glider measurements made during and after the flood (19-20 March 2011). The values at a distance of $2.5 \mathrm{~km}$ off the coast are derived from the bottom-mounted ADCP measurement at the POEM station (squares). 
The cross-shelf and along-shelf vertically averaged components of the currents, water and particle transports across the shelf after the flood are presented in Fig. 10. Cross-shelf current, as well as water and particulate transports increased seaward from the coast. The instantaneous cumulative cross-shelf transport of water and particles on the inner and mid-shelf amounted to $1.7 \times 10^{5} \mathrm{~m}^{3} \mathrm{~s}^{-1}$ and $0.2 \mathrm{t} \mathrm{s}^{-1}$ respectively. The along-shelf component of the current and transports were close to zero on the inner shelf. They increased and were oriented southwards on the mid-shelf, due to strong geostrophic currents at the level of the density front, and reversed farther seaward. Hence, the instantaneous cumulated along-shelf water and particulate transport across the section nearly cancelled out and amounted to $1.0 \times 10^{5} \mathrm{~m}^{3} \mathrm{~s}^{-1}$ and $0.1 \mathrm{t} \mathrm{s}^{-1}$ respectively. Values of depth-averaged current, water transport and particulate transport at the POEM site based on ADCP measurements at $28 \mathrm{~m}$ depth are reported on Fig. 10 and are of the same order but significantly bigger than glider estimated values at the coast: $-0.12 \mathrm{~m} \mathrm{~s}^{-1},-0.4 \times 10^{4} \mathrm{~m}^{3} \mathrm{~s}^{-1}$, and $0.02 \mathrm{t} \mathrm{s}^{-1}$ respectively.

Time series of cumulative water and particulate cross-shelf and along-shelf transports for the different glider sections performed between early March to late March are presented in Fig. 11(a and b). Strong southward along-shelf transports prevailed during the stormy period with maximum cross-shelf and along-shelf transport $\left(+0.5\right.$ and $-3.9 \mathrm{t} \mathrm{s}^{-1}$ respectively) during the $14-15$ March storm. Both transport components dropped markedly afterwards, while exhibiting a weak northward along-shelf transport. Cumulative particle transport was normalized by the surface of the
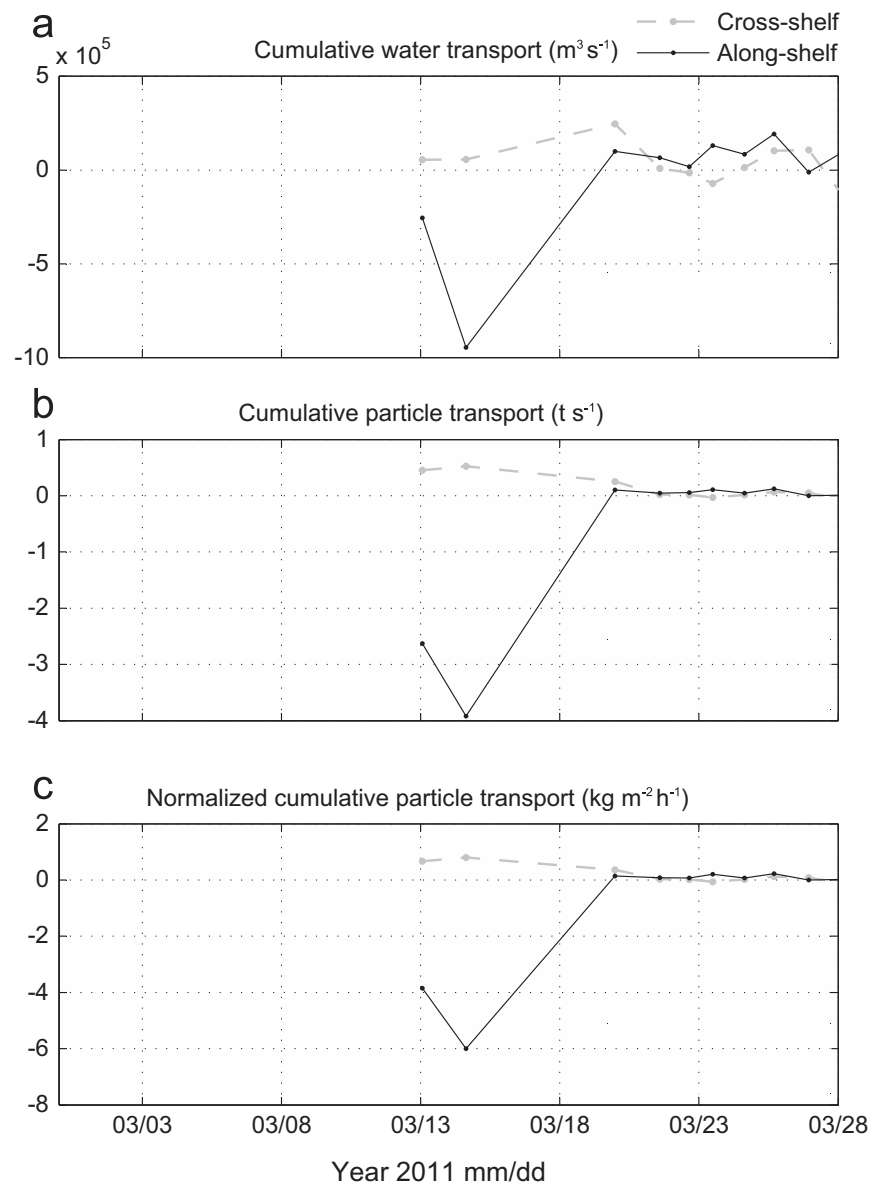

Fig. 11. Cumulated water (a) and particle (b) transports along the glider's cross shelf section between mid-March to late March 2011 (see Fig. 1 for the transects location). (c) Cumulative along and cross-shelf particle transport estimated from bottom-mounted ADCP measures at the POEM station. glider section to compare with ADCP transport measurements of Fig. 6e and is shown on Fig. 11c. ADCP-derived cumulative transport was also maximum during the storm with peak values of +5 and $-25 \mathrm{~kg} \mathrm{~m}^{2} \mathrm{~h}^{-1}$ in the cross-shelf and along-shelf directions, while glider derived cumulative transport show values of +1 and $-6 \mathrm{~kg} \mathrm{~m}^{2} \mathrm{~h}^{-1}$ respectively.

\subsubsection{Canyon observations}

The impact of the storms was simultaneously observed at the coastal POEM site and the Cap de Creus Canyon head (Fig. 12). During the stormy period (13-15 March) the potential temperature at 8 mab within the canyon head rapidly decreased from $12.8^{\circ} \mathrm{C}$ to $11.5^{\circ} \mathrm{C}$, which was approximately the same temperature observed on the shelf (Fig. 12c). After the storms, the canyon head potential temperature increased to its pre-storm value. The impact of the storms was also shown by the salinity signal within the canyon head, which slightly decreased during the stormy period from 38.2 to 37.8 and returned to previous values after the storms (Fig. 12d). Subsurface salinity at the coast decreased rapidly from 35.5 to 16 during the flooding period but no corresponding change was observed inside the canyon during the same period. Current magnitude (Fig. 12e) both at the coast and in the canyon head increased rapidly during the storms and reached maximum values$$
\text { a }
$$

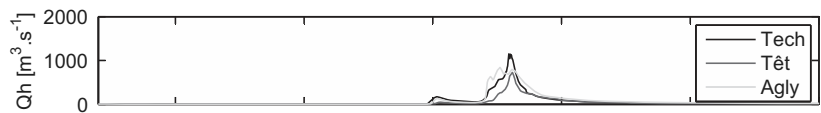

b

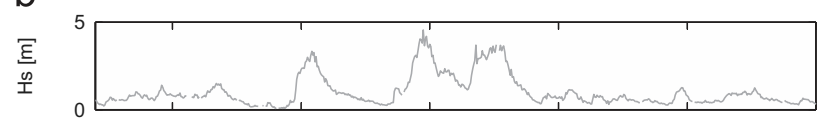

C

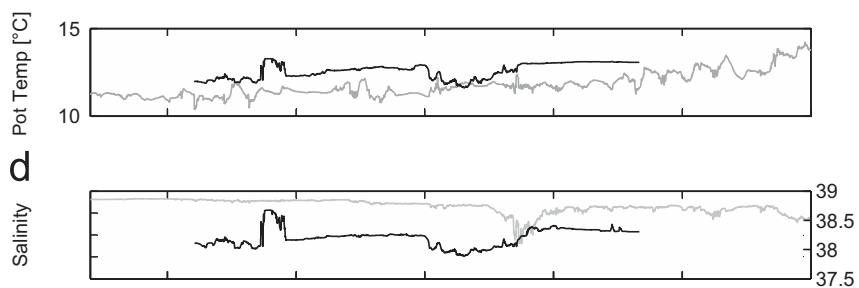

e

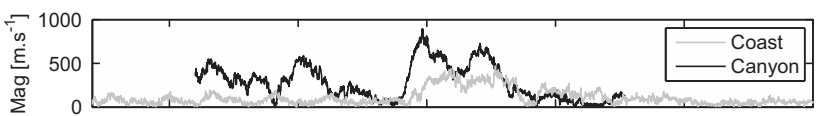

f

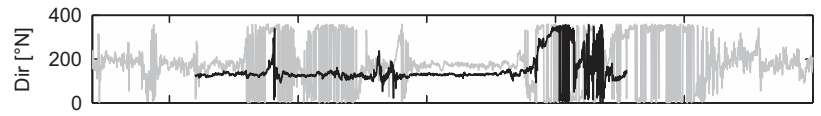

9

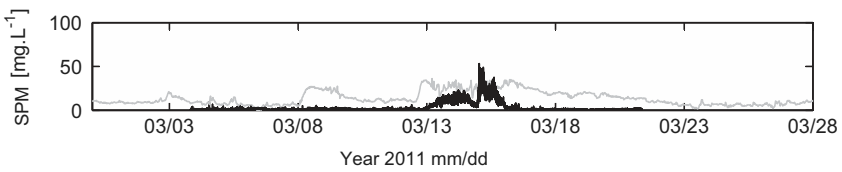

Fig. 12. Simultaneous data time-series from the POEM site at $28 \mathrm{~m}$ depth and the Cap de Creus Canyon head at 265 m depth: (a) hourly river discharge of Pyrenean coastal rivers, (b) significant wave height at the coastal site, (c) potential temperature at the coast (blue, sub-surface CTD) and in the canyon (red, CTD 8 mab at $265 \mathrm{~m}$ depth), (d) salinity at the coast (blue, sub-surface CTD) and in the canyon (red, CTD $8 \mathrm{mab}$ at $265 \mathrm{~m}$ depth) (e, f) current magnitude and direction from ADCPs (blue, 2 mab at $28 \mathrm{~m}$ depth; red, $160 \mathrm{mab}$ at $265 \mathrm{~m}$ depth), (g) SPM concentrations (blue, ADCP-derived at the coast and red, OBS-derived, 10 mab at $265 \mathrm{~m}$ ). (For interpretation of the references to colour in this figure legend, the reader is referred to the web version of this article.) 
of 50 and $90 \mathrm{~cm} \mathrm{~s}^{-1}$ respectively. Currents were southward at both sites during the consecutive stormy events (Fig. 12f). The nearbottom SPM concentrations at the coast increased to $20 \mathrm{mg} \mathrm{L}^{-1}$ during the first storm ( 8 March), but no change was observed in the canyon head (Fig. 12g). The SPM concentrations increased again at the coast during the following storm (13 March) and remained at values between 15 and $35 \mathrm{mg} \mathrm{L}^{-1}$ until the 21 March. In the canyon head, a first increase of SPM concentrations up to $25 \mathrm{mg} \mathrm{L}^{-1}$ was observed about $12 \mathrm{~h}$ after the storm peak of the 13 March, and the second increase up to $50 \mathrm{mg} \mathrm{L}^{-1}$ was reached concomitantly during the third storm peak on the 15 March.

\subsection{Suspended particle properties}

Optical properties of suspended particles during the last storm (14-15 March 2011) and after the flood (18-21 March) are presented in Figs. 13 and 14 respectively. During the stormy period (Fig. 13), suspended particles on the inner shelf displayed the largest total backscattering signal $\left(b_{\mathrm{bp}}\right.$ at $\left.700 \mathrm{~nm}\right)$ with values between 0.05 and $0.45 \mathrm{~m}^{-1}$. These coastal particles were also characterized by high Chl-a concentrations with values between 1 and $1.2 \mu \mathrm{g} \mathrm{L}^{-1}$. Contrarily, particles further offshore presented a weaker total backscattering signal $\left(<0.03 \mathrm{~m}^{-1}\right)$ and lower Chl-a concentrations $\left(<0.8 \mu \mathrm{g} \mathrm{L}^{-1}\right)$ (Fig. 13a). Coastal particles presented lower values of $\gamma$ index $(<0.5)$ than the offshore particles $(>0.7)$ (Fig. 13b).

After the flooding period (Fig. 14), the total backscattering signal was relatively low $\left(<0.05 \mathrm{~m}^{-1}\right)$, with respect to the stormy period. Coastal particles exhibited the highest backscattering signal $\left(\sim 0.05 \mathrm{~m}^{-1}\right)$ and Chl-a concentrations (up to $1.6 \mu \mathrm{g} \mathrm{L}^{-1}$ ) (Fig. 14a). Coastal particles also presented slightly lower values of $\gamma$ index $(<0.6)$ than the offshore particles (0.7-0.8) (Fig. 14b).

\section{Discussion}

\subsection{Variability of hydrological structures and suspended particulate} matter transport

Back-to-back storm and flood events are a typical feature in the Gulf of Lions, and are designated as "wet storms" (Guillén et al., 2006). However their impact on the shelf hydrology, hydrodynamics and particle transport have been barely documented because weather conditions are usually too energetic for seagoing missions. The few studies that described sediment transport during such events were carried out from bottom-mounted instruments deployed on the inner shelf close to the Têt (Guillén et al., 2006; Bourrin et al., 2008a, b) or the Rhône (Marion et al., 2010) river mouths.

The present measurements at the POEM buoy and across the shelf during the storms and after the flood show a very rapid change, within a few days, of hydrological structures on the inner and middle shelf. The core of dense coastal water present at the end of February/early March is typical of winter conditions during which cold and dense water is formed along the coast of the GoL under the influence of strong northerly winds. These dense waters spread towards the south-eastern end of the GoL and are mainly exported to the northern Catalan shelf or the continental slope in the vicinity of the Cap de Creus Canyon (Ulses et al., 2008c). The dynamics of dense shelf water is sensitive to the wind intensity. In a modelling work on the same area during the winter of 2005 , during which very dense water was formed, Bourrin et al. (2008a) showed that the dense water core is confined to the coast when northerly winds are strong and that a bottom layer, similar to that observed on the glider section (Fig. 7), detached from the main core and extended towards the mid-shelf when the wind subsides.
As seen on the cross-shelf section, and also shown by Martín et al. (2013) from observations gathered in the Cap de Creus Canyon, the density of nearshore waters observed during March 2011, however, is barely larger than the outer-shelf waters and weaker than the slope water, which suggests that the volume of dense water present on the shelf in early March was probably small. Moreover, E-SE storms strongly influence the dynamics of water masses on the continental shelf. The observations clearly show an important southward along-shelf flow on the inner and middle shelf, which is characteristic of the intense cyclonic circulation that takes place during E-SE storms (Ulses et al., 2008b). These currents induce a rapid transport and massive flushing of dense water off the shelf into the Cap de Creus Canyon (Palanques et al., 2006, 2008) or towards the Catalan shelf, south of the Cape de Creus peninsula (Ribó et al., 2011). Bourrin et al. (2008b) showed that during a storm and flood event in the same area, both SPM eroded on the inner-shelf by waves and SPM introduced by freshwater inputs were rapidly advected by along-shelf currents southward towards the canyons but did not evidence the presence of cold waters on the shelf. In the present study, the large inputs of fresher water during the river floods ensuing the stormy period produce a large buoyant plume that takes the place of the dense coastal water. Thus, observations at the coast and across the shelf reveal extremely rapid and drastic changes in water masses, stratification and flow on the entire shelf by consecutive storm and flood events in wintertime (Figs. 7 and 9).

Surface sediment responds quickly to increasing shear stress. Significant sediment erosion and transport take place within hours of the onset of the storms. Observations of bottom shear stress and seabed elevation (Fig. 6), which show erosion over several centimetres during the storm, corroborate the observations made by Guillén et al. (2006) at the same point during the winter 20032004 under the impact of E-SE storms with significant wave heights between 3 and $8 \mathrm{~m}$. Compared to these aforementioned studies, the new observations gathered with the glider across the shelf provide essential information on the evolution of the SPM distribution and transport in the water column. The observed structures show a strong horizontal concentration gradient across the shelf with significant decrease beyond the mid shelf (Fig. 7d). During the storms, the cumulative along-shelf transport is an order of magnitude higher than the cross-shelf transport, and remains confined to the inner shelf where velocities and resuspension due to waves are strongest (Fig. 8). Significant transport, both in the along- and cross-shelf directions, is associated to the bottom plume of dense water that spreads on the mid and outer-shelf. The observations collected concomitantly in the Cap de Creus Canyon (Martín et al., 2013) clearly indicated that the water and SPM transported along the shelf during the storm rapidly reach (in less than half a day) the southern exit of the GoL. Considering a range of southward SPM transport along the glider's cross-shelf section of $2-4 \mathrm{t} \mathrm{s}^{-1}$ during the $12-16$ March storm period (Fig. 11b), the total SPM transport during this 5-day long period amounts between 0.9 and $2.1 \times 10^{6}$ t, knowing that this quantity does not take into account the transport within the coastal band shallower than $30 \mathrm{~m}$ due to the glider limitation. The transport on the inner-shelf is approximated to $0.09 \times 10^{6} \mathrm{t}$ considering a triangular section for the inner shelf below $30 \mathrm{~m}$ water depth $\left(3.75 \cdot 10^{4} \mathrm{~m}^{2}\right)$ and the average transport measured at the POEM station during the stormy period $\left(\sim 20 \mathrm{~kg} \mathrm{~m}^{-2} \mathrm{~h}^{-1}\right)$. The total transport through the cross shelf Sections ( $\sim 1$ and $2.2 \times 106 \mathrm{t}$ ) is about one order of magnitude larger than the SPM transport estimated by Martín et al. (2013) as being transferred along the southern canyon flank of the Cap de Creus during the storm-induced downwelling $\left(\sim 1 \times 10^{5} \mathrm{t}\right)$. Hence, due to the weak density contrast of coastal waters with the slope waters, it appears that most of the transport bypassed the Cap de Creus Canyon towards the northern Catalan shelf, while only a 


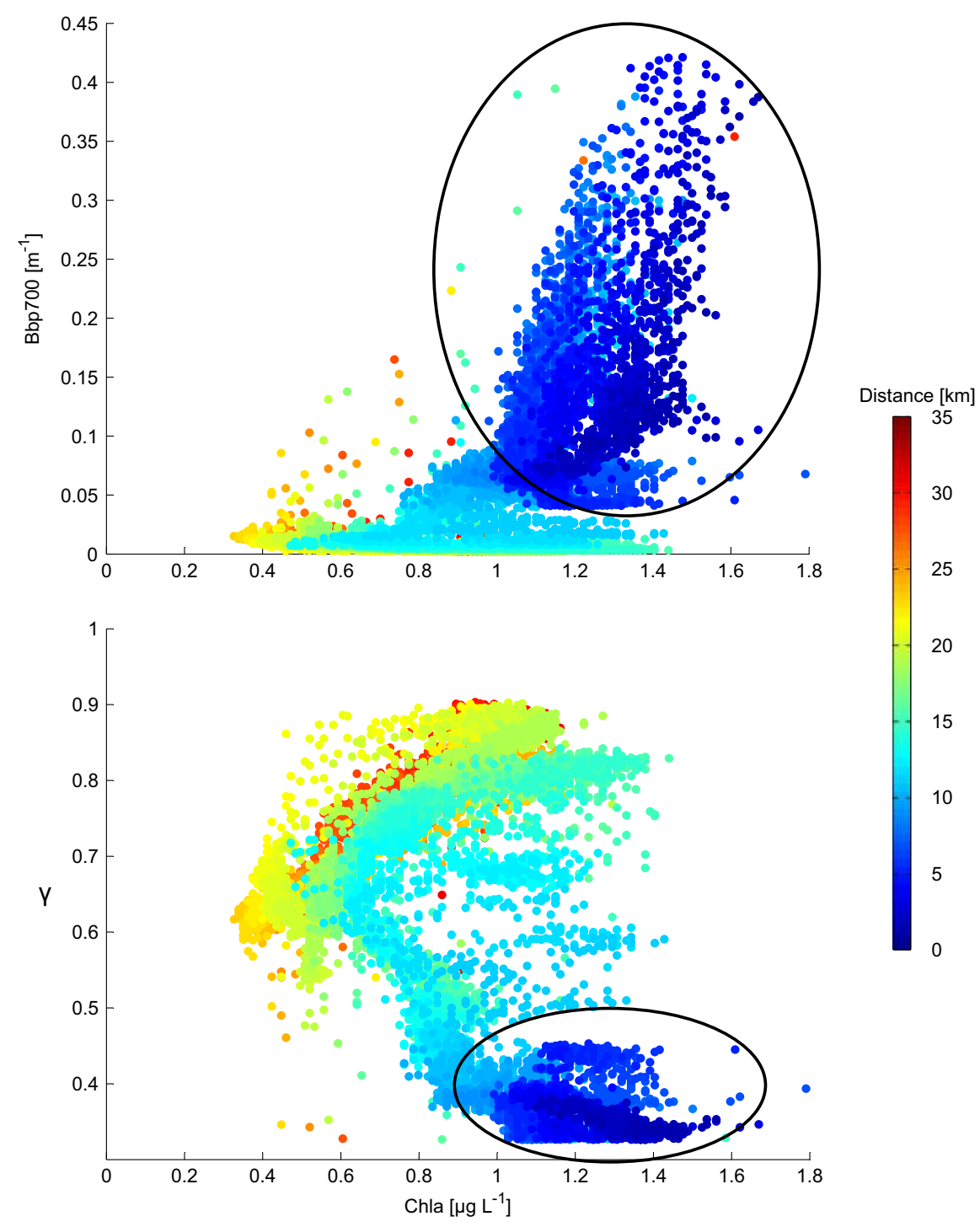

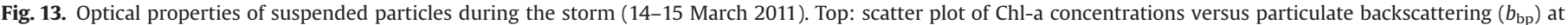

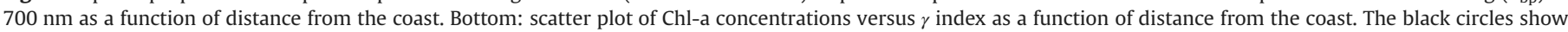
the characteristics of particles inside the storm bottom nepheloid layer.

limited fraction (around 5-10\%) was exported to the upper canyon. Furthermore the SPM transport through the cross shelf section during the storm is comparable to the total solid river discharge to the GoL during the subsequent flooding period (13-18 March) that was estimated as $0.9 \times 10^{6} \mathrm{t}$.

The seaward variation of the cross-shelf particulate transport generates a divergence between 30 and $50 \mathrm{~m}$ depth, and a convergence between 60 and $80 \mathrm{~m}$ depth. The divergence on the inner shelf can be related to the high bottom shear stress combined with off-shelf current during storm, which are effective at removing fine sediments and transport them seaward. Conversely, the convergence on the mid-shelf can lead to a deposition of the coarsest particles in suspension. There is a fairly clear correspondence between the outer limit of the mid-shelf mud belt and the limit at which the cross-shelf transport vanishes. The presence of fine sediment on the mud belt, that can be easily resuspended, nonetheless probably contributes to the supply of the bottom nepheloid layer, which extends on the distal part of the mid-shelf (between roughly 15 and $25 \mathrm{~km}$ off the coast). These results conform well to expectations from the academic modelling study of Harris and Wiberg (2002), which concluded that on narrow, steep shelf (seabed slope $\sim 0.05 \%$ ), such as the study area (mean slope $\sim 0.045 \%$ between 0 and $90 \mathrm{~m}$ water depths), the cross-shelf flux convergence of fine grained sediment enhances the storm beds formed at mid-shelf depths. Further, our observations indicate that despite the decrease of wave-induced shear stress with increasing depth, strong storm currents (between 30 and $50 \mathrm{~cm} \mathrm{~s}^{-1}$ ) taking place on the mid and outer-shelf likely produce a winnowing of fine sediment. This is also consistent with the modelling studies of Ulses et al. (2008a) and Dufois et al. (2008), which indicated significant erosion on the outer-shelf by strong bottom currents during storm events.

\subsection{Variability of suspended particles properties}

The abrupt change of the hydrological structures on the shelf between the stormy and flooding periods is also visible on the suspended particles properties. The spectral slope of backscattering signal at 3 different wavelengths measured from the glider is used to estimate the spatio-temporal variability of particles. The overall seaward increase of $\gamma$ both for stormy (Fig. 13b) and flooding (Fig. 14b) conditions would imply that coastal 


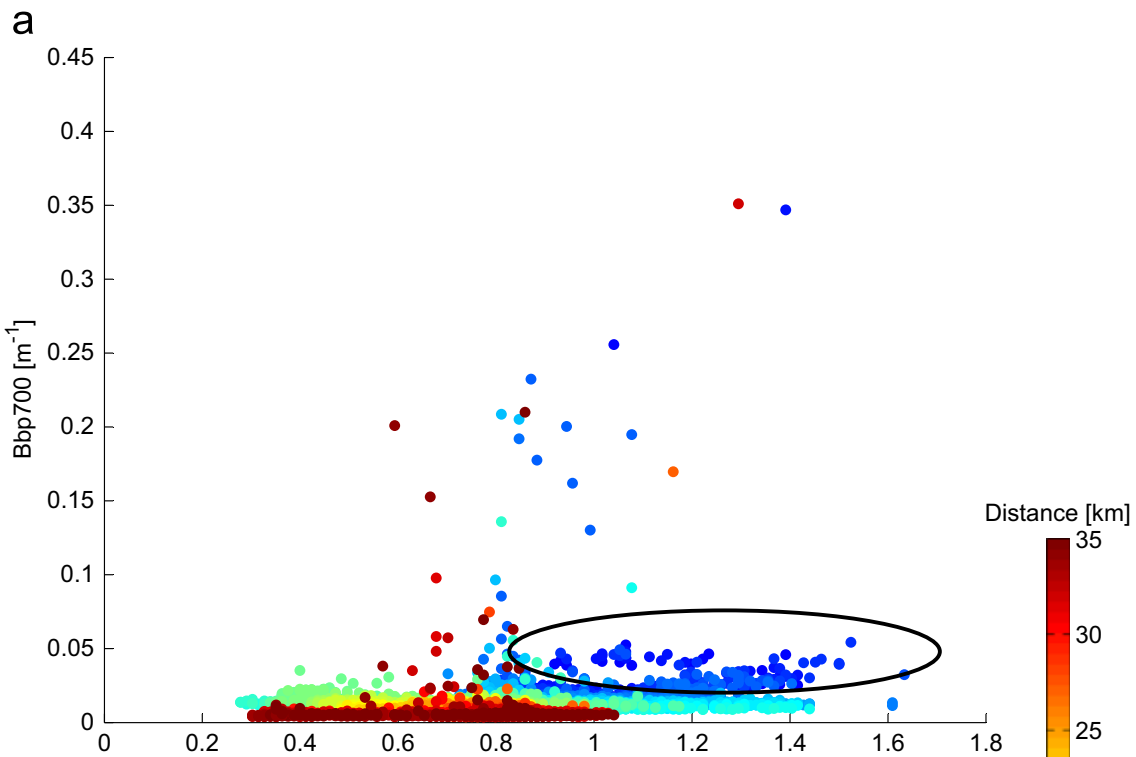

b

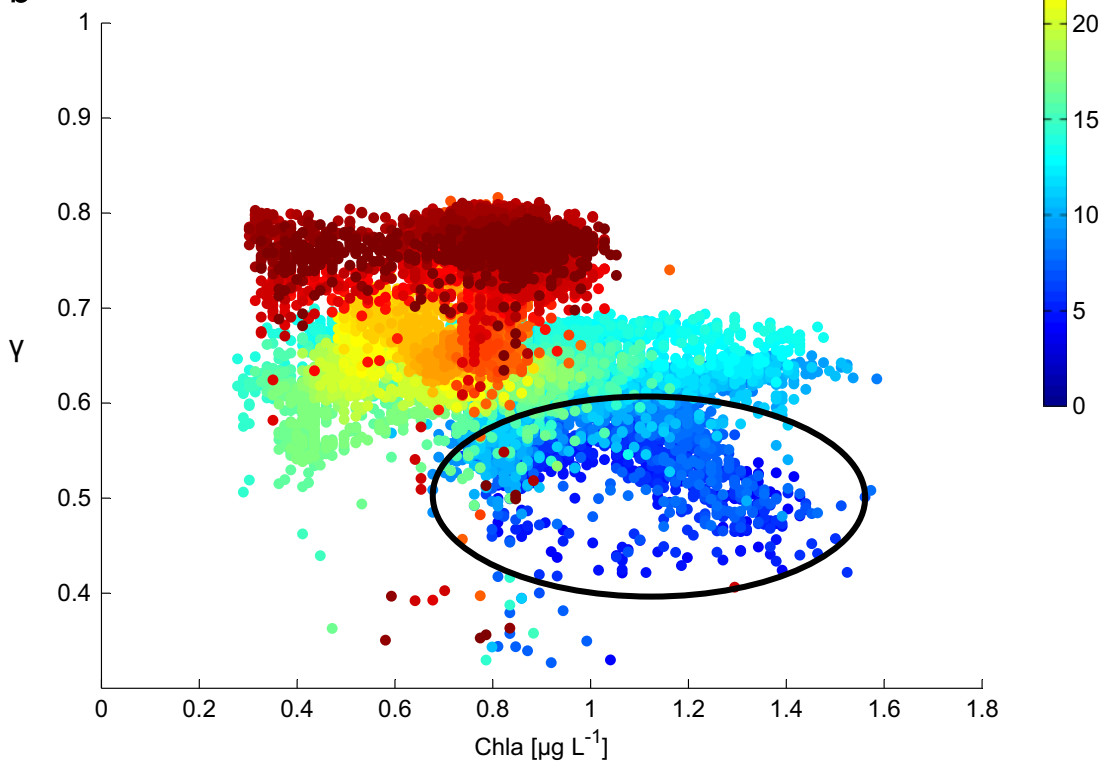

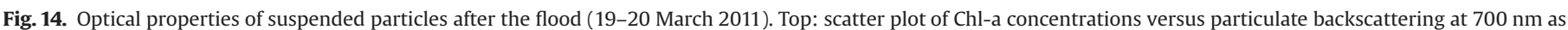

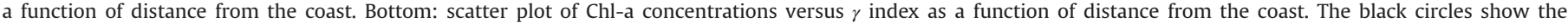
characteristics of particles inside the flood bottom nepheloid layer and the surface river plume.

particles assemblage is composed by a higher percentage of large particles than the offshore particles assemblage. This seaward decrease of particles size was also suggested by Niewiadomska et al. (2008) in a coastal front system off the Riviera coast in the NW Mediterranean using the same method. The use of an optically derived $\gamma$ index was first used for the global ocean to estimate from satellite data the contribution of small versus large suspended particles (Loisel et al., 2006). The present study is one the first study describing the characteristics and size of the suspended particles assemblage from glider based measurements in the coastal area. Futures studies need more investigations in order to compare this index with in-situ grain-size analysis and calibrate measurements form autonomous platforms.

As is shown in greater detail in Fig. 15a, the turbid bottom nepheloid layer that developed between 5 and $10 \mathrm{~km}$ from the shoreline during the storm is primarily composed of coarse particles. Both suspended sediment concentration (Fig. 7d) and particle size (Fig. 15b) decrease with increasing distance from the seabed. Such changes are consistent with particle resuspension and settling in the bottom layer, two processes that are dependant on particle size and density. The resuspension also appears to be effective above the mid-shelf mud belt where the percentage of fine sediments is maximum (Fig. 1). This maximum also corresponds to the current convergence where the coarsest particles are likely to be deposited. It is believed that coarse particles present in the bottom nepheloid layer can be flocs formed by the stirring and aggregation of single fine particles that are resuspended from the inner-shelf sediment. As a matter of fact, Durrieu de Madron et al. (2005) and Curran et al. (2007) show that clayey and fine silty resuspended particles tends to form flocs populations (from microflocs around $30 \mu \mathrm{m}$ to macroflocs $>100 \mu \mathrm{m}$ ). Besides, the high Chl-a concentrations suggest that particles of biological origin (Fig. 13a, b) probably also contribute to the large particles pool.

After the storm, the bottom nepheloid layer mostly constituted of coarse particles was rapidly swept away and advected towards the Cap de Creus Canyon and the northern Catalan shelf. During the flooding period, only a thin and diffuse bottom nepheloid layer persists on the shelf (Fig. 9d). This layer is less turbid, has a weaker 


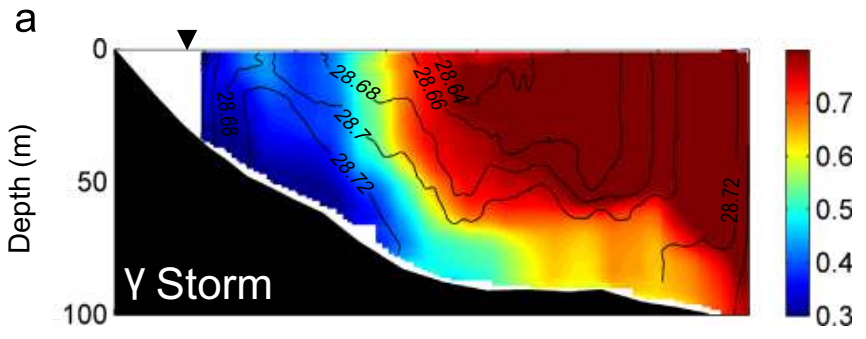

b

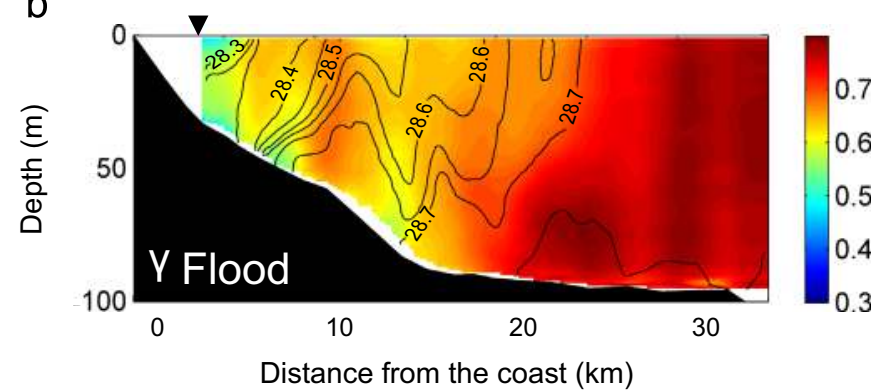

Fig. 15. Cross-shelf glider section of gamma index during the storm (a) and after the flood (b).

Chl-a content, and is composed of finer particles than during the stormy period (Fig. 15b). This kind of bottom nepheloid layer has been often observed on the continental shelf of the Gulf of Lions and is considered to be permanent. The decrease of the concentration of mineral and biological particles in suspension, and the lower turbulence during this period could explain the diminution of particle size. The surface turbid plume associated to the flooding of the coastal rivers has the same characteristics in terms of backscattering spectral dependency than the flood bottom nepheloid layer. This layer appears to have the same relative grain-size as the bottom nepheloid layer, but is probably composed by different particles because of the higher Chl-a content. However, this statement must be considered carefully since we have relatively few measurements inside the river plumes because of the extension of the surface plume and the low capacity of the glider to go very close to the coast.

\section{Conclusions}

This work provided a unique synoptic view across the entire shelf of the impact of a typical Mediterranean storm on bottom sediment erosion and particulate fluxes. Repeated glider transects across the south-western part of the Gulf of Lions shelf permitted for the first time to measure continuously the thermo-haline structures, the suspended particles concentrations, the current speed, and to estimate the particulate transport before, during and after typical Mediterranean storm events. Glider data complement and compare well with concomitant high frequency time series at fixed stations along the coast and in a downstream submarine canyon.

Particulate matter transport was primary along-shelf, and higher above the mid-shelf mud belt, which is composed of more easily erodible fine sediment. A seaward cross-shelf transport occurs on the inner-shelf and part of the mid-shelf and vanishes further offshore, evidencing a convergence flux likely implying a deposition of particles on the distal part of the mid-shelf. Most of the transport of shelf water during the E-SE storm exits rapidly the Gulf of Lions shelf, a small part downwelled towards the Cap de Creus Canyon head, while the rest was exported towards the northern Catalan shelf.

We used the spectral relationship between the particulate backscattering coefficient and the wavelength of the backscattering sensors to estimate the gamma index, which is a proxy of the particle size in the coastal zone. This index shows that the largest particles were confined at the coast, and in the bottom nepheloid layer, where the SPM concentrations are the largest, whereas the smallest particles are located offshore. Further investigations with in-situ grain size measurements have to be done to confirm the effectiveness of this index.

\section{Acknowledgements}

This work was funded by the HERMIONE Project (FP7-ENV2008-1-226354) under the European Commission's Seventh Framework Program, the MERMEX project under the MISTRALS Programme, and the TUCPA project under the CNRS EC2CO DRILL Programme. We also thank the SOERE MOOSE for supporting and providing long-term observation data in the Gulf of Lions. We thank Anthony Boss for his help in glider data formatting and for providing useful Matlab routines.

\section{References}

Bonnin, J., Heussner, S., Calafat, A., Fabres, J., Palanques, A., Durrieu de Madron, X. Canals, M., Puig, P., Avril, J., Delsaut, N., 2008. Comparison of horizontal and downward particle fluxes across canyons of the Gulf of Lions (NW Mediterranean): meteorological and hydrodynamical forcing. Cont. Shelf Res. 28, 1957-1970. http://dx.doi.org/10.1016/j.csr.2008.06.004.

Boss, E., Pegau, W.S., Gardner, W.D., Zaneveld, J.R.V., Barnard, A.H., Twardowski, M. S., Chang, G., Dickey, T., 2001a. Spectral particulate attenuation and particle size distribution in the bottom boundary layer of a continental shelf. J. Geophys. Res.: Oceans 106, 9509-9516 (1978-2012).

Boss, E., Twardowski, M.S., Herring, S., 2001b. Shape of the particulate beam attenuation spectrum and its inversion to obtain the shape of the particulate size distribution. Appl. Opt. 40, 4885-4893.

Bourrin, F., Durrieu de Madron, X., Ludwig, W., 2006. Contribution to the study of coastal rivers and associated prodeltas to sediment supply in the Gulf of Lions (NW Mediterranean Sea). Vie et Milieu 56 (4), 307-314.

Bourrin, F., Durrieu de Madron, X., Heussner, S., Estournel, C., 2008a. Impact of winter dense water formation on shelf sediment erosion (evidence from the Gulf of Lions, NW Mediterranean). Cont. Shelf Res. 28, 1984-1999. http://dx.doi. org/10.1016/j.csr.2008.06.006.

Bourrin, F., Friend, P.L., Amos, C.L., Manca, E., Ulses, C., Palanques, A., Durrieu de Madron, X., Thompson, C.E.L., 2008b. Sediment dispersal from a typical Mediterranean flood: the Têt River, Gulf of Lions. Cont. Shelf Res. 28, 1895-1910. http://dx.doi.org/10.1016/j.csr.2008.06.005.

Cattaneo, A., Trincardi, F., Asioli, A., Correggiari, A., 2007. The Western Adriatic shelf clinoform: energy-limited bottomset. Cont. Shelf Res. 27, 506-525. http://dx. doi.org/10.1016/j.csr.2006.11.013.

Corbett, D.R., Walsh, J.P., Harris, C.K., Ogston, A.S., Orpin, A.R., 2014. Formation and preservation of sedimentary strata from coastal events: Insights from measurements and modeling. Cont. Shelf Res. 86, 1-5.

Curran, K., Hill, P., Milligan, T., Mikkelsen, O., Law, B., Durrieu de Madron, X., Bourrin, F., 2007. Settling velocity, effective density, and mass composition of suspended sediment in a coastal bottom boundary layer, Gulf of Lions, France. Cont. Shelf Res. 27, 1408-1421.

Davis, R.E., Eriksen, C.C., Jones, C.P., 2002. Autonomous buoyancy-driven underwater gliders. Technol. Appl. Auton. Underw. Veh., 37-58.

DeGeest, A.L., Mullenbach, B.L., Puig, P., Nittrouer, C.A., Drexler, T.M., Durrieu de Madron, X., Orange, D.L., 2008. Sediment accumulation in the western Gulf of Lions, France: the role of Cap de Creus Canyon in linking shelf and slope sediment dispersal systems. Cont. Shelf Res. 28, 2031-2047. http://dx.doi.org/ 10.1016/j.csr.2008.02.008

Doxaran, D., Ruddick, K., McKee, D., Gentili, B., Tailliez, D., Chami, M., Babin, M., 2009. Spectral variations of light scattering by marine particles in coastal waters, from visible to near infrared. Limnol. Oceanogr. 54, 1257 (OS).

DREAL, 2011. DREAL_LR-rapport_coup_de_mer_12-16_mars_2011.

Dufois, F., Garreau, P., Le Hir, P., Forget, P., 2008. Wave- and current-induced bottom shear stress distribution in the Gulf of Lions. Cont. Shelf Res. 28, 1920-1934. http://dx.doi.org/10.1016/j.csr.2008.03.028.

Durrieu de Madron, X., Wiberg, P.L., Puig, P., 2008. Sediment dynamics in the Gulf of Lions: the impact of extreme events. Cont. Shelf Res. 28, 1867-1876. http://dx. doi.org/10.1016/j.csr.2008.08.001.

Durrieu de Madron, X., Ferré, B., Le Corre, G., Grenz, C., Conan, P., Pujo-Pay, M., Buscail, R., Bodiot, O., 2005. Trawling-induced resuspension and dispersal of muddy sediments and dissolved elements in the Gulf of Lion (NW Mediterranean). Cont. Shelf Res. 25, 2387-2409. http://dx.doi.org/10.1016/j.csr.2005.08.002. 
Eau France, 2011. Bulletin National de Situation Hydrologique [WWW Document]. URL: 〈http://www.eaufrance.fr/docs/bsh/2011/04/precipitations.php〉 (accessed 07.10.14.).

Ferré, B., Durrieu de Madron, X., Estournel, C., Ulses, C., Le Corre, G., 2008. Impact of natural (waves and currents) and anthropogenic (trawl) resuspension on the export of particulate matter to the open ocean: application to the Gulf of Lion (NW Mediterranean). Cont. Shelf Res. 28, 2071-2091. http://dx.doi.org/10.1016/ j.csr.2008.02.002.

Ferré, B., Guizien, K., Durrieu de Madron, X., Palanques, A., Guillén, J., Grémare, A 2005. Fine-grained sediment dynamics during a strong storm event in the inner-shelf of the Gulf of Lion (NW Mediterranean). Cont. Shelf Res. 25 2410-2427. http://dx.doi.org/10.1016/j.csr.2005.08.017.

Garau, B., Ruiz, S., Zhang, W.G., Pascual, A., Heslop, E., Kerfoot, J., Tintoré, J., 2011. Thermal Lag Correction on Slocum CTD Glider Data. J. Atmos. Ocean. Technol. 28, 1065-1071. http://dx.doi.org/10.1175/JTECH-d-10-05030.1.

Glenn, S., Jones, C. Twardowski, M., Bowers, L., Kerfoot, J., Kohut, J., Webb, D. Schofield, O., 2008. Glider observations of sediment resuspension in a Middle Atlantic Bight fall transition storm. Limnol. Oceanogr. 53, 2180-2196.

Gohin, F., Stanev, E., 2011. Annual cycles of chlorophyll-a, non-algal suspended particulate matter, and turbidity observed from space and in-situ in coastal waters. Ocean Sci. 7, 705-732.

Guillén, J., Bourrin, F., Palanques, A., Durrieu de Madron, X., Puig, P., Buscail, R., 2006. Sediment dynamics during wet and dry storm events on the Têt inner shelf (SW Gulf of Lions). Mar. Geol. 234, 129-142. http://dx.doi.org/10.1016/j. margeo.2006.09.018.

Guillén, J., Palanques, A., Puig, P., Durrieu de Madron, X., Nyffeler, F., 2000. Field calibration of optical sensors for measuring suspended sediment concentration in the western Mediterranean. Sci. Mar. 64 (4), 427-435.

Guizien, K., 2009. Spatial variability of wave conditions in the Gulf of Lions (NW Mediterranean sea). Vie et Milieu 59, 261.

Harris, C.K., Wiberg, P., 2002. Across-shelf sediment transport: interactions between suspended sediment and bed sediment. J. Geophys. Res.: Oceans 107, 8-11. http://dx.doi.org/10.1029/2000JC000634.

Hay, A.E., 1991. Sound scattering from a particle-laden, turbulent jet. J. Acoust. Soc Am. 90, 2055-2074.

Hill, P.S., Fox, J.M., Crockett, J.S., Curran, K.J., Friedrichs, C.T., Geyer, W.R., Milligan, T. G., Ogston, A.S., Puig, P., Scully, M.E., 2007. Sediment delivery to the seabed on continental margins. Continental-Margin Sedimentation: from Sediment Transport to Sequence Stratigraphy. IAP Special Publication, vol. 37. pp. 49-100

Loisel, H., Nicolas, J.-M., Sciandra, A., Stramski, D., Poteau, A., 2006. Spectral dependency of optical backscattering by marine particles from satellite remote sensing of the global ocean. J. Geophys. Res. 111, C09024. http://dx.doi.org/ 10.1029/2005JC003367.

Madsen, O.S., Wood, W., 2002. Sediment transport outside the surf zone. Coastal Engineering Manual, Part III Coastal Processes, Engineer Manual. pp. 1110-1112.

Marion, C., Dufois, F., Arnaud, M., Vella, C., 2010. In situ record of sedimentary processes near the Rhône River mouth during winter events (Gulf of Lions, Mediterranean Sea). Cont. Shelf Res. 30 (9), 1095-1107.

Martín, J., Durrieu de Madron, X., Puig, P., Bourrin, F., Palanques, A., Houpert, L., Higueras, M., Sanchez-Vidal, A., Calafat, A.M., Canals, M., Heussner, S., Delsaut, N., Sotin, C., 2013. Sediment transport along the Cap de Creus Canyon flank during a mild, wet winter. Biogeosciences 10, 3221-3239. http://dx.doi.org/ 10.5194/bg-10-3221-2013.

McCave, I.N., 1972. Transport and escape of fine-grained sediment from shelf areas, Shelf Sediment Transport: Process and Pattern. Dowden, Hutchinson, and Ross, Stroudsburg, Pennsylvania, pp. 225-248.

Miles, T., Glenn, S.M., Schofield, O., 2013. Temporal and spatial variability in fall storm induced sediment resuspension on the Mid-Atlantic Bight. Cont. Shelf Res. 63 (Suppl.), S36-S49. http://dx.doi.org/10.1016/j.csr.2012.08.006.

Moore, D.G., 1969. Reflection Profiling Studies of the California Continental Borderland: Structure and Quaternary Turbidite Basins. Geological Society of America, United States.

Morel, A., 1974. Optical properties of pure water and pure sea water. Opt. Asp. Oceanogr., 1, 1 - 24.
Morison, J., Andersen, R., Larson, N., Dasaro, E., Boyd, T., 1994. The correction for thermal-lag effects in Sea-Bird CTD data. J. Atmos. Ocean. Technol. 11, 1151-1164.

Niewiadomska, K., Claustre, H., Prieur, L., d’ Ortenzio, F., 2008. Submesoscale physical-biogeochemical coupling across the Ligurian current (northwestern Mediterranean) using a bio-optical glider. Limnol. Oceanogr. 53, 2210.

Nittrouer, C.A., Austin Jr., J.A., Field, M.E., Kravitz, J.H., Syvitski, J.P.M., Wiberg, P.L., 2007. Writing a Rosetta stone: insight into continental margin sedimentary processes and strata. In: Nittrouer, C.A., Austin Jr, J.A., Field, M.E., Kravitz, J.H., Syvitski, J.P.M., Wiberg, P.L. (Eds.), Continental Margin Sedimentation: from Sediment Transport to Sequence Stratigraphy,

pp. 1-48 (Special publication number 37 of the International Association of Sedimentologists)

Ogston, A.S., Drexler, T.M., Puig, P., 2008. Sediment delivery, resuspension, and transport in two contrasting canyon environments in the southwest Gulf of Lions. Cont. Shelf Res. 28, 2000-2016. http://dx.doi.org/10.1016/j. csr.2008.02.012.

Palanques, A., Durrieu de Madron, X., Puig, P., Fabres, J., Guillén, J., Calafat, A., Canals, M., Heussner, S., Bonnin, J., 2006. Suspended sediment fluxes and transport processes in the Gulf of Lions submarine canyons. The role of storms and dense water cascading. Mar. Geol. 234, 43-61. http://dx.doi.org/10.1016/j. margeo.2006.09.002.

Palanques, A., Guillén, J., Puig, P., Durrieu de Madron, X., 2008. Storm-driven shelfto-canyon suspended sediment transport at the southwestern Gulf of Lions. Cont. Shelf Res. 28, 1947-1956. http://dx.doi.org/10.1016/j.csr.2008.03.020.

Pond, S., Pickard, G.L., 1983. Introductory dynamical oceanography, 2nd ed. Pergamon Press, New York, p. 329.

Ribó, M., Puig, P., Palanques, A., Lo Iacono, C., 2011. Dense shelf water cascades in the Cap de Creus and Palamós submarine canyons during winters 2007 and 2008. Mar. Geol. 284, 175-188. http://dx.doi.org/10.1016/j.margeo.2011.04.001.

Sullivan, J.M., Donaghay, P.L., Rines, J.E.B., 2010. Coastal thin layer dynamics: consequences to biology and optics. Cont. Shelf Res. 30, 50-65. http://dx.doi.org/ 10.1016/j.csr.2009.07.009.

Teledyne RD Instruments, 2007. WAVES PRIMER: Wave Measurements and the RDI ADCP Waves Array Technique. Available from 〈RDInstruments.com〉.

Testor, P., Meyers, G., Pattiaratchi, C., Bachmayer, R., Hayes, D., Pouliquen, S., Petit de la Villeon, L., Carval, T., Ganachaud, A., Gourdeau, L., 2010. Gliders as a component of future observing systems. In: Proceedings of OceanObs' 09: Sustained Ocean Observations and Information for Society, vol. 2.

Thorne, P.D., Campbell, S.C., 1992. Backscattering by a suspension of spheres. J. Acoust. Soc. Am. 92, 978-986.

Ulses, C., Estournel, C., Durrieu de Madron, X., Palanques, A., 2008a. Suspended sediment transport in the Gulf of Lions (NW Mediterranean): impact of ex treme storms and floods. Cont. Shelf Res. 28; a, pp. 2048-2070. http://dx.doi. org/10.1016/j.csr.2008.01.015.

Ulses, C., Estournel, C., Bonnin, J., Durrieu de Madron, X., Marsaleix, P., 2008b. Impacts between storms and dense water cascading on shelf-slope exchange in the Gulf of Lions (NW Mediterranean). J. Geophys. Res. 113, C02010. http://dx. doi.org/10.1029/2006JC003795.

Ulses, C., Estournel, C., Puig, P., Durrieu de Madron, X., Marsaleix, P., 2008c. Dense water cascading in the northwestern Mediterranean during the cold winter 2005. Quantification of the export through the Gulf of Lion and the Catalan margin. Geophys. Res. Lett. 35, L07610. http://dx.doi.org/10.1029/ 2008 GL033257.

Wallingford, H.R., 2003. The Sediview Method, Sediview Procedure Manual. July 2003, vol. 3, 88 pp.

Weaver, P.P.E., Canals, M., Trincardi, F., 2006. EUROSTRATAFORM special Issue of marine geology. Mar. Geol. 234, 1-2. http://dx.doi.org/10.1016/j. margeo.2006.09.001.

Webb Research, Operations Manual Slocum Shallow Battery Glider Ver 1.6 1/11/ 2005.

Wright, L., Coleman, J.M., 1974. Mississippi river mouth processes: effluent dynamics and morphologic development. J. Geol., 751-778. 